\title{
Adaptation Independent Modulation of Auditory Hair Cell Mechanotransduction Channel Open Probability Implicates a Role for the Lipid Bilayer
}

\author{
Anthony W. Peng, ${ }^{1,4}$ Radhakrishnan Gnanasambandam, ${ }^{3}$ Frederick Sachs, ${ }^{3}$ and Anthony J. Ricci ${ }^{1,2}$ \\ Departments of ${ }^{1}$ Otolaryngology, Head and Neck Surgery and ${ }^{2}$ Molecular and Cellular Physiology, Stanford University School of Medicine, Stanford, \\ California 94025, ${ }^{3}$ Center for Single Molecule Biophysics, Department of Physiology and Biophysics, University at Buffalo, State University of New York, \\ Buffalo, New York 14214, and ${ }^{4}$ Department of Physiology and Biophysics, University of Colorado Denver, Anschutz Medical Center, Aurora, Colorado \\ 80045
}

The auditory system is able to detect movement down to atomic dimensions. This sensitivity comes in part from mechanisms associated with gating of hair cell mechanoelectric transduction (MET) channels. MET channels, located at the tops of stereocilia, are poised to detect tension induced by hair bundle deflection. Hair bundle deflection generates a force by pulling on tip-link proteins connecting adjacent stereocilia. The resting open probability $\left(P_{\text {open }}\right)$ of MET channels determines the linearity and sensitivity to mechanical stimulation. Classically, $P_{\text {open }}$ is regulated by a calcium-sensitive adaptation mechanism in which lowering extracellular calcium or depolarization increases $P_{\text {open }}$. Recent data demonstrated that the fast component of adaptation is independent of both calcium and voltage, thus requiring an alternative explanation for the sensitivity of $P_{\text {open }}$ to calcium and voltage. Using rat auditory hair cells, we characterize a mechanism, separate from fast adaptation, whereby divalent ions interacting with the local lipid environment modulate resting $P_{\text {open }}$. The specificity of this effect for different divalent ions suggests binding sites that are not an EF-hand or calmodulin model. GsMTx4, a lipid-mediated modifier of cationic stretch-activated channels, eliminated the voltage and divalent sensitivity with minimal effects on adaptation. We hypothesize that the dual mechanisms (lipid modulation and adaptation) extend the dynamic range of the system while maintaining adaptation kinetics at their maximal rates.

Key words: $\mathrm{Ca}^{2+}$ regulation; GsMTx4; hair cell; lipid regulation; mechanotransduction; stereocilia

\section{Significance Statement}

Classically, changes in extracellular calcium and voltage affect open probability $\left(P_{\text {open }}\right)$ through mechanoelectric transduction adaptation, and this mechanism is the only means of controlling the set point of the channel. Here, we further characterize the effects of extracellular calcium and voltage on the channel and for the first time determine that these manipulations occur through a mechanism that is independent of fast adaptation and involves the lipid bilayer. These data additionally demonstrate that effects on $P_{\text {open }}$ are not enough to characterize adaptation and thus may clarify some of the discrepancies within the literature as to mechanisms underlying adaptation.

\section{Introduction}

Sound or head motion induce mechanical stimulation of stereociliary hair bundles protruding from the apical surface of inner

\footnotetext{
Received Aug. 7, 2015; revised Jan. 22, 2016; accepted Jan. 29, 2016.

Author contributions: A.W.P. and A.J.R. designed research; A.W.P. performed research; R.G. and F.S. contributed unpublished reagents/analytic tools; A.W.P. and A.J.R. analyzed data; A.W.P., F.S., and A.J.R. wrote the paper.

This work was supported by National Institutes of Health Grants K99/R00 DC013299 (A.W.P.), R01 DC003896 (A.J.R.), and P30-44992. R.G. and F.S. are supported by National Institutes of Health Grant R01 HL054887.

F.S. is President of Tonus Therapeutics, which is developing clinical uses for GsMTx4. All other authors declare no competing financial interests.

Correspondence should be addressed to either of the following: Anthony W. Peng, Department of Physiology and Biophysics, University of Colorado Denver, Anschutz Medical Center, 12800 East 19th Avenue, Room 7127, MS 8307, Aurora, C0 80045, E-mail: anthony.peng@ucdenver.edu; or Anthony J. Ricci, Department of Otolaryngology, Head
}

ear sensory hair cells (Hudspeth and Corey, 1977). Hair bundle deflection applies force to tip-link proteins that connect the stereocilia of adjacent rows (Pickles et al., 1984). This force is coupled to mechanoelectric transduction (MET) channels located near the tops of the shorter stereocilia and regulates their open probability $\left(P_{\text {open }}\right)$ (Beurg et al., 2009).

The auditory system is able to detect movement at atomic dimensions (Bialek, 1987). To maximize the sensitivity of the

and Neck Surgery, Stanford University, School of Medicine, 300 Pasteur Drive, Edwards R135, MC 5365, Stanford, CA 94305, E-mail: aricci@stanford.edu.

DOI:10.1523/JNEUROSCI.3011-15.2016

Copyright $\odot 2016$ the authors $\quad 0270-6474 / 16 / 362945-12 \$ 15.00 / 0$ 
system, most auditory hair cells have channel open probabilities set at the steepest part of their activation curve [current-displacement $(I-X)$ curve], so $\sim 50 \%$ of the channels are open at rest (Ricci et al., 1998; Farris et al., 2006; Johnson et al., 2011). An adaptation process regulates the set point of the activation curve to maintain sensitivity and extend the dynamic range of the hair bundle (Eatock et al., 1987; Gillespie and Cyr, 2004; Fettiplace and Kim, 2014). Tonotopic variations in adaptation kinetics contribute to the mechanical filtering of incoming signals (Ricci and Fettiplace, 1997; Kennedy et al., 2003; Ricci et al., 2005). In lower vertebrates (e.g., turtles and frogs), calcium $\left(\mathrm{Ca}^{2+}\right)$ entry through the MET channel drives two components of adaptation: (1) $\mathrm{Ca}^{2+}$ binding to calmodulin modulates a slow motor process; and (2) $\mathrm{Ca}^{2+}$ acts at an unknown intracellular site to regulate a fast adaptation process (Crawford et al., 1989, 1991; Assad and Corey, 1992; Walker and Hudspeth, 1996; Ricci et al., 1998; Wu et al., 1999). The current view is that adaptation equilibrates the local force and intracellular $\mathrm{Ca}^{2+}$ to determine the channel set point. Recent work in the mammalian cochlea suggests that the fast component of adaptation, defined as adaptation occurring in $<5 \mathrm{~ms}$, is independent of $\mathrm{Ca}^{2+}$ and that there is very little slow adaptation (Peng et al., 2013).

The resting $P_{\text {open }}$ of the MET channel is an indicator of the set point of the steady-state activation curve. The set point is sensitive to extracellular $\mathrm{Ca}^{2+}$ and membrane potential (Corey and Hudspeth, 1983; Eatock et al., 1987; Assad et al., 1989; Crawford et al., 1989, 1991; Ricci et al., 1998; Farris et al., 2006; Johnson et al., 2011; Corns et al., 2014). Classically, adaptation is the sole regulator of $P_{\text {open }}$, so that changes in $P_{\text {open }}$ are often used as indicators of the state of adaptation (Corns et al., 2014, 2016; Fettiplace and Kim, 2014). Similar to lower vertebrates, $P_{\text {open }}$ in mammalian auditory hair cells is also modulated by extracellular $\mathrm{Ca}^{2+}$ and voltage (Beurg et al., 2010; Johnson et al., 2011; Zampini et al., 2011; Peng et al., 2013; Corns et al., 2014). However, as fast adaptation appears independent of $\mathrm{Ca}^{2+}$, what mechanism regulates $P_{\text {open }}$ ?

Here, we show that the effects of voltage and extracellular $\mathrm{Ca}^{2+}$ modulate a mechanism that acts via the lipid bilayer. The set point of these MET channels is modulated by extracellular divalent ions with a selectivity based on their ionic radius and by membrane potential. GsMTx4, which is an amphiphilic modifier of stretch-activated channels, can inhibit the effect of divalents and voltage while fast adaptation is intact, therefore, by itself, $P_{\text {open }}$ is not a unique readout of adaptation. This new mechanism we discovered may enhance the dynamic range of the cell while preventing saturation of adaptation.

\section{Materials and Methods}

Preparation and recordings. Animals were killed by decapitation using methods approved by the Stanford University Administrative Panel on Laboratory Animal Care. Organs of Corti were dissected from postnatal day 6 (P6) to P10 Sprague Dawley rats (large majority of experiments used P7-P8) of either sex and placed in recording chambers as described previously (Beurg et al., 2009). Tissue was viewed using a 60 or $100 \times(1.0$
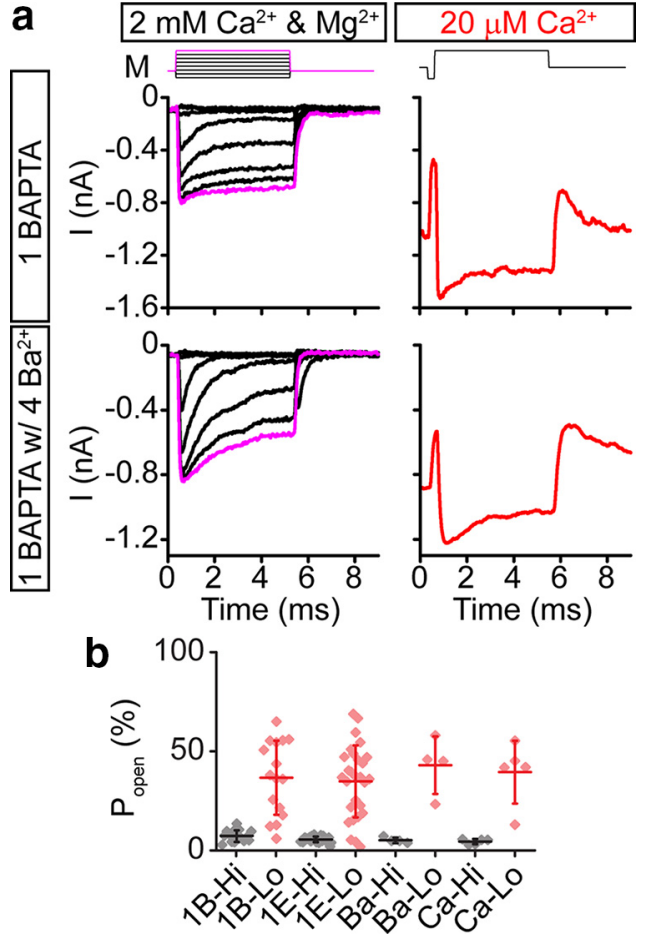

Figure 2. Low extracellular $\mathrm{Ca}^{2+}$ modulation of $P_{\text {open }}$ is attributable to extracellular binding sites. $\boldsymbol{a}$, When decreasing extracellular $\mathrm{Ca}^{2+}$ to $20 \mu \mathrm{m}$, resting $P_{\text {open }}$ increases. A family of step responses for control traces (black; $2 \mathrm{~mm} \mathrm{Ca}^{2+}$ and $2 \mathrm{mM} \mathrm{Mg}^{2+}$ divalent ions) are presented in the left column, and a single protocol with a large negative followed by a large positive stimulation for $20 \mu \mathrm{M} \mathrm{Ca}^{2+}$ (red) are presented to illustrate the resting $P_{\text {open }}$ of the channels. In a normal 1 mм BAPTA internal solution (top traces), resting $P_{\text {open }}$ shifts to $\sim 50 \%$ when decreasing extracellular $\mathrm{Ca}^{2+}$. Adding $4 \mathrm{~mm} \mathrm{Ba}^{2+}$ to the internal solution (bottom traces) had no effect on the ability to shift the resting $P_{\text {open }}$, suggesting that the site of divalent action is extracellular. $M$ indicates the driving voltage to the piezoelectric stack. The maximum positive stimulation is shown in magenta. $\boldsymbol{b}$, Summary of resting $P_{\text {open }}$ in $2 \mathrm{~mm} \mathrm{Ca}^{2+}$ and $\mathrm{Mg}^{2+}(\mathrm{Hi})$ and $20 \mu \mathrm{m}$ extracellular $\mathrm{Ca}^{2+}(\mathrm{Lo})$ in different internal solutions. 1B, 1 mм BAPTA $(n=16)$; $1 \mathrm{E}, 1 \mathrm{~mm}$ EGTA $(n=28) ; \mathrm{Ba}, 1 \mathrm{~mm}$ BAPTA with $4 \mathrm{~mm} \mathrm{Ba}^{2+}(n=4) ; C a, 1.4 \mathrm{~mm}$ free $\mathrm{Ca}^{2+}(n=5$, data reanalyzed from Peng et al., 2013). Each point is a different cell with mean \pm SD shown. 

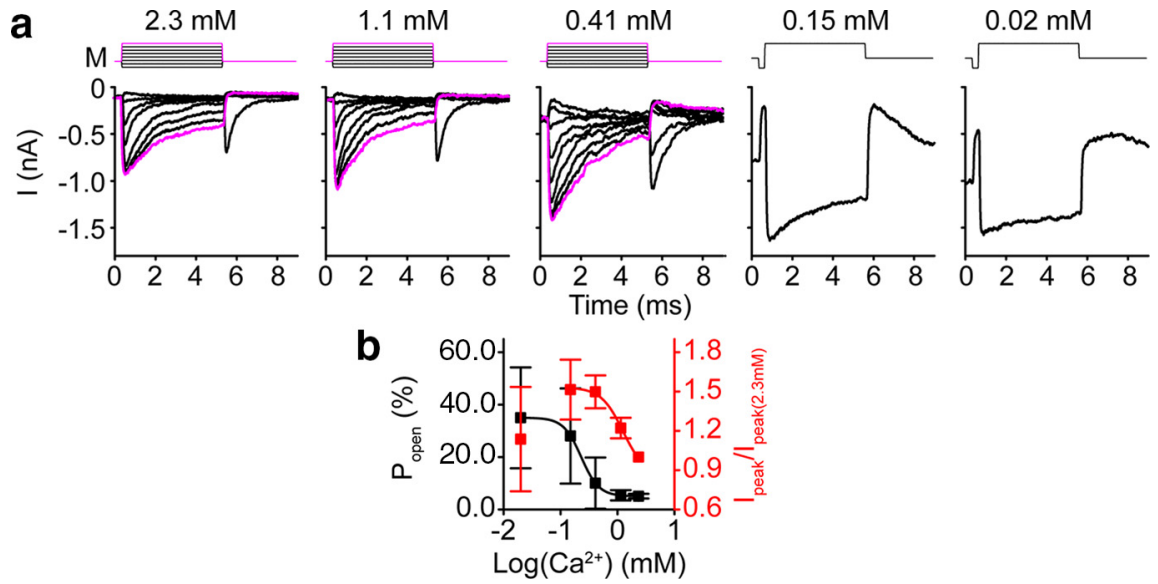

Figure 3. Dose-response curves differ for the resting $P_{\text {open }}$ effect and the peak current change. $\boldsymbol{a}, \mathrm{A}$ family of curves was generated in the $\mathrm{Ca}^{2+}$ concentrations stated above the plots. For the lower concentrations, a single stimulus was used with a large negative stimulation proceeded by a large positive stimulation to estimate the resting $P_{\text {open }}$. A full family of curves was not generated in these cases because the hair bundle became more susceptible to mechanical damage during stimulation at lower $\mathrm{Ca}^{2+}$ concentrations. M indicates the mechanical stimulus used. The maximum positive stimulation is shown in magenta when family of curves was obtained. $\boldsymbol{b}$, Resting $P_{\text {open }}$ was calculated from curves generated in $\boldsymbol{a}$, and dose-response curves for $P_{\text {open }}$ were generated using all cells, but some cells died before a complete series was obtained. From lowest to highest $\mathrm{Ca}^{2+}$ concentration, $n=12,15,17,17$, and 17. $I_{50}, 0.23 \pm 0.001 \mathrm{~mm}$; Hill slope, $2.8 \pm 0.01$ (value \pm SE). Additionally, the peak current change was also measured and normalized to the peak current in $2.3 \mathrm{~mm} \mathrm{Ca}{ }^{2+}$. For the lowest $\mathrm{Ca}^{2+}$ concentration, the current was often smaller likely attributable to damage, presumably by breakage of tip-links, so the red fitignores this data point $\left[\mathrm{IC}_{50}, 1.1 \pm 0.3 \mathrm{~mm}\right.$; Hill slope, $5.5 \pm 6.5$ (value \pm SE)]. Each data point shows mean \pm SD.
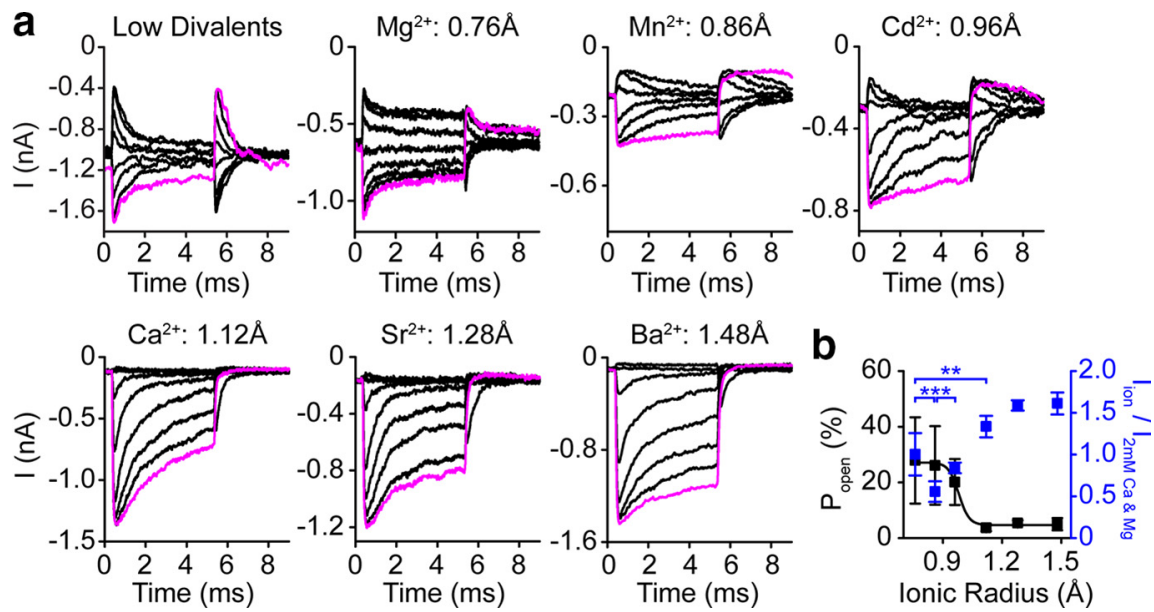

Figure 4. Extracellular divalent ions modulate the MET resting $P_{\text {open }} . \boldsymbol{a}, \mathrm{A}$ family of step responses recorded in each solution containing $2 \mathrm{~mm}$ of the indicated divalent ion (radius of the ions is also indicated; Persson, 2010) shows that only specific divalent ions can prevent a shift in the resting $P_{\text {open }}$. Low divalents indicate a solution with no added divalent ions and is buffered with HEDTA (see Materials and Methods, HEDTA-buffered solution). The maximum positive stimulation is shown in magenta. $\boldsymbol{b}$, Summary of the resting $P_{\text {open }}$ plotted against the divalent ion radius (left axis; black symbols; from left to right, $\mathrm{Mg}^{2+}, \mathrm{Mn}^{2+}$, $\mathrm{Cd}^{2+}, \mathrm{Ca}^{2+} \mathrm{Sr}^{2+}$, and $\mathrm{Ba}^{2+}$ with $n=11,8,7,9,6$, and 7, respectively; shown as mean $\pm \mathrm{SD}$ ). A sigmoidal fit (black line) shows a monotonic function of $P_{\text {open }}$ versus ionic radius. The peak mechanically sensitive current normalized against the control current (in $2 \mathrm{~mm} \mathrm{Ca}^{2+}$ and $2 \mathrm{~mm} \mathrm{Mg}^{2+}$ ) shows a non-monotonic change, indicating that the binding sites responsible for the resting $P_{\text {open }}$ are unique from the ones controlling peak current (right axis; blue symbols). Only significance values to neighboring points that indicate the non-monotonicity are shown. Each data point shows mean \pm SD. ${ }^{* *} p<0.01,{ }^{* *} p<0.001$.

numerical aperture; Olympus) water-immersion objective with a digital Rolera XR (Qimaging) or Phantom Miro 320s (Vision Research) camera on a BX51 microscope (Olympus). Tissue was dissected and perfused with extracellular solution containing the following (in $\mathrm{mM}$ ): $140 \mathrm{NaCl}, 2$ $\mathrm{KCl}, 2 \mathrm{CaCl}_{2}, 2 \mathrm{MgCl}_{2}, 10$ HEPES, 2 creatine monohydrate, $2 \mathrm{Na}-$ pyruvate, 2 ascorbic acid, and 6 dextrose, $\mathrm{pH} 7.4$ (300-310 mOsm). In addition, an apical perfusion, with pipette tip sizes of $150-300 \mu \mathrm{m}$, provided local perfusion to the hair bundles (Fig. 1). In all preparations, the tectorial membrane is peeled off the tissue.
Electrophysiological recordings. Whole-cell patch clamp is achieved on first- or second-row outer hair cells (OHCs) from middle to apical cochlear turns using an Axon 200B amplifier (Molecular Devices) with thick-walled borosilicate patch pipettes $(2-6 \mathrm{M} \Omega$ ) filled with an intracellular solution containing the following (in mM): $125 \mathrm{CsCl}, 3.5 \mathrm{MgCl}_{2}, 5 \mathrm{ATP}, 5$ creatine phosphate, 10 HEPES, 1 cesium BAPTA, and 3 ascorbic acid, pH 7.2 (280-290 mOsm). For the $4 \mathrm{~mm} \mathrm{Ba}^{2+}$ with $1 \mathrm{~mm}$ BAPTA internal solution, $4 \mathrm{~mm} \mathrm{BaCl}_{2}$ was added. For the EGTA internal solution, 1 mM EGTA replaced cesium BAPTA and ascorbic acid increased to $4 \mathrm{~mm}$. The $1.4 \mathrm{Ca}^{2+}$ internal solution contained the following (in mM): $121 \mathrm{CsCl}, 3.5 \mathrm{MgCl}_{2}, 3.5$ $\mathrm{CaCl}_{2}, 3.5$ ATP, 5 creatine phosphate, 10 HEPES, and 2 ascorbic acid, pH 7.2 (280-290 $\mathrm{mOsm})$. Experiments were performed at 18 $22^{\circ} \mathrm{C}$. Whole-cell currents were filtered at 10 or $100 \mathrm{kHz}$ and sampled at $0.05-1 \mathrm{MHz}$ using USB-6356 (National Instruments) controlled by jClamp (SciSoft). Voltages were corrected offline for liquid junction potentials. All experiments used $-84 \mathrm{mV}$ holding potential unless otherwise noted. For inclusion, initial MET currents $>600 \mathrm{pA}$ in $2 \mathrm{~mm}$ extracellular $\mathrm{Ca}^{2+}$ and $\mathrm{Mg}^{2+}$ were required.

Hair bundle stimulation. Borosilicate pipettes were fire polished to shapes that matched the hair bundle structures for OHCs. Probes were driven by a piezoelectric stack [AE0505D08F (Thorlabs) or PSt 150/7x7/7 (APC International)] whose input was filtered using an eight-pole Bessel filter (L8L 90PF; Frequency Devices) at $10-30 \mathrm{kHz}$ and variably attenuated (PA5; Tucker Davis) before being sent to a high-voltage/high-current amplifier to drive the piezoelectric stack. Experiments with the Pep Intl GsMTx4 used a fluid jet stimulation. Position of the hair bundle was determined using high-speed imaging of the stimulation at 10,000 frames/s using the Phantom Miro 320s and extracted using a Gaussian fit to a bandpass-filtered hair bundle image intensity profile.

Extracellular solution perfusion. N-(Hydroxyethyl)-ethylenediaminetriacetic acid (HEDTA)-buffered solution contained the following (in $\mathrm{mm}$ ): $150 \mathrm{NaCl}, 2 \mathrm{KCl}, 3.3 \mathrm{CaCl}_{2}, 4$ HEDTA, and 10 HEPES, pH 7.4 (310 mOsm). Free $\mathrm{Ca}^{2+}$ concentrations were measured at 20 $\mu \mathrm{M}$ using a MI-600 $\mathrm{Ca}^{2+}$ electrode (Microelectrodes) calibrated using $\mathrm{Ca}^{2+}$ buffer standards (CALBUF-2; WPI). The extracellular perfusion solutions at $2 \mathrm{mM}, 1 \mathrm{mM}, 300 \mu \mathrm{M}$, and 100 $\mu \mathrm{M} \mathrm{Ca}{ }^{2+}$ contained the following: $157 \mathrm{~mm}$ $\mathrm{NaCl}, 2$ mм KCl, 10 mм HEPES, pH 7.4, 305$320 \mathrm{mOsm}$, and 2, 1, 0.3, and $0.08 \mathrm{~mm} \mathrm{CaCl}_{2}$, respectively. These solutions had measured $\mathrm{Ca}^{2+}$ concentrations of $2.34,1.14,0.41$, and $0.15 \mathrm{~mm}$, respectively. The $\mathrm{Mg}^{2+}, \mathrm{Ca}^{2+}, \mathrm{Sr}^{2+}, \mathrm{Ba}^{2+}, \mathrm{Mn}^{2+}$, and $\mathrm{Cd}^{2+}$ solutions were composed of the following (in mM): $154 \mathrm{NaCl}, 2 \mathrm{KCl}, 10$ HEPES, and $2 \mathrm{MgCl}_{2}, \mathrm{CaCl}_{2}, \mathrm{SrCl}_{2}, \mathrm{BaCl}_{2}, \mathrm{MnCl}_{2}$, or $\mathrm{CdCl}_{2}$, respectively, pH 7.4 (305-320 mOsm). The $\mathrm{Mg}^{2+}, \mathrm{Sr}^{2+}, \mathrm{Ba}^{2+}, \mathrm{Mn}^{2+}$, and $\mathrm{Cd}^{2+}$ solutions had measured free $\mathrm{Ca}^{2+}$ concentrations of $20,45,19,18$, and $43 \mu \mathrm{M}$, respectively.

An apical perfusion pipette was used for solution application via a six-inlet manifold (Warner Instruments) using a custom gravity flow 

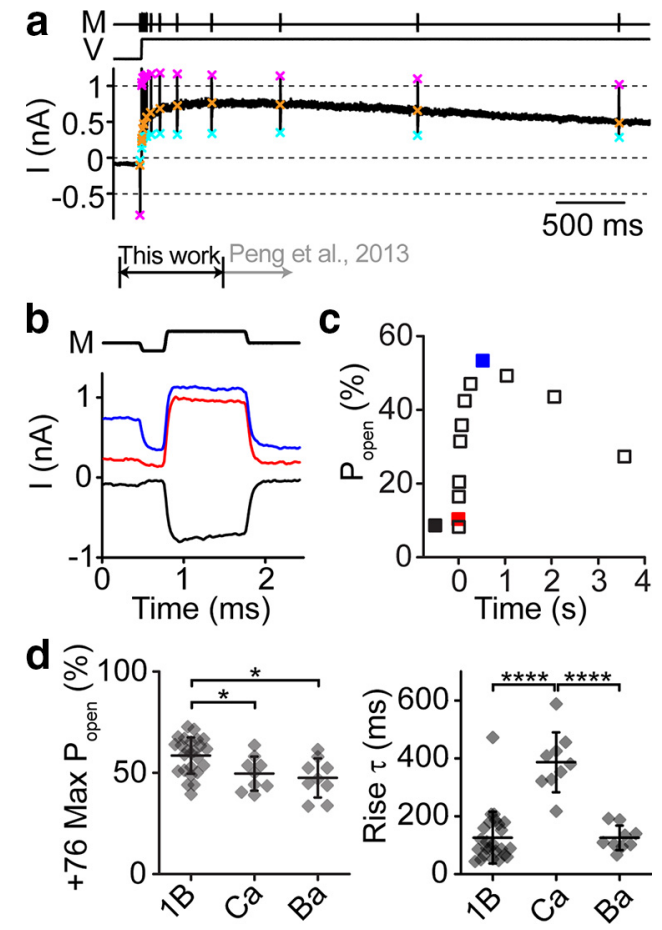

Figure 5. Voltage modulates the MET resting $P_{\text {open }} \cdot \boldsymbol{a}$, In response to a depolarization to 76 $\mathrm{mV}$, the resting $P_{\text {open }}$ of an $\mathrm{OHC}$ channel increases to $\sim 50 \%$. Resting $P_{\text {open }}$ is determined at each point using a fast negative and positive stimulus $(M)$ to get the peak-to-peak mechanically sensitive current. Cyan $\times$ symbols indicate the negative displacement current, orange $\times$ symbols the resting current, and magenta $\times$ symbols the positive displacement current. The current work focuses on the changes within the first second of depolarization (black arrow). Previous work described the longer timescale changes (gray arrow). $\boldsymbol{b}$, Magnified current response of single fast negative and positive stimuli from the protocol in $\boldsymbol{a}$ for an $\mathrm{OHC}$ shows the changes in resting $P_{\text {open }}$ before the depolarization (black), immediately after depolarization (red), and $\sim 300 \mathrm{~ms}$ after depolarization when the resting $P_{\text {open }}$ has peaked (blue). c, Plot of the change in $P_{\text {open }}$ during the depolarization. Traces shown in $\boldsymbol{b}$ are indicated here as filled color symbols. The negative potential data point has an arbitrary negative time value. $\boldsymbol{d}$, Summary of the maximum $P_{\text {open }}$ reached at $76 \mathrm{mV}$ for different internal solutions (left) and the time constant of a single-exponential fit to the rise of $P_{\text {open }}$. Each point is a different cell with mean \pm SD shown. 1B, $1 \mathrm{~mm}$ BAPTA $(n=25) ; \mathrm{Ca}, 1.4 \mathrm{~mm}$ free $\mathrm{Ca}^{2+}(n=9) ; \mathrm{Ba}, 1 \mathrm{~mm}$ BAPTA with $4 \mathrm{~mm}$ $\mathrm{Ba}^{2+}(n=9) .{ }^{*} p<0.05,{ }^{* * * *} p<0.0001$.

perfusion system. Pipette tips were broken to $150-300 \mu \mathrm{m}$ in diameter to allow perfusion of a wide area around the recorded hair cell, thus ensuring that the concentration of $\mathrm{Ca}^{2+}$ at the hair bundle was that in the perfusion solution. The perfusion rate was set by looking at the flow into a bath of water to give a boundary of the flow that did not diverge greatly from the pipette tip size.

The $\mathrm{L}$ and D isomers of GsMTx4 (Protonin) was synthesized as described previously (Suchyna et al., 2004). GsMTx4 at $0.5 \mathrm{mg}$ was dissolved into $610 \mu \mathrm{l}$ of extracellular solution for a $200 \mu \mathrm{M}$ stock solution and was frozen. The solution was diluted to 2 or $3 \mu \mathrm{M}$ on the day of the experiment. Data for these two concentrations are pooled. For the Peptides International GsMTx4, $0.11 \mathrm{mg}$ was dissolved directly into $13.5 \mathrm{ml}$ of extracellular solution.

Data analysis. $I-X$ plots, generated by subtracting leak current defined as the smallest remaining current during the negative steps and normalizing to the peak current, were fit with a double Boltzmann equation:

$$
y=\frac{I_{\max }}{1+e^{Z_{2}\left(x_{0}-x\right)}\left(1+e^{Z_{1}\left(x_{0}-x\right)}\right)},
$$

where $Z_{1}$ and $Z_{2}$ are the slope factors, and $x_{0}$ is the set point.

For mechanical stimulus steps, adaptation time constant fits were obtained at $\sim 50 \%$ peak current using a double-exponential decay:

$$
y=y_{0}+A_{1} e^{-\left(x-x_{0}\right) / \tau_{1}}+A_{2} e^{-\left(x-x_{0}\right) / \tau_{2}},
$$

where $\tau_{1}$ and $\tau_{2}$ are the decay constants, and $A_{1}$ and $A_{2}$ are the respective amplitudes.

The dose-response curve was fit using the following equation:

$$
y=A_{1}+\frac{A_{2}+A_{1}}{1+10^{\log \left(x_{0}-x\right) p}}
$$

where $A_{1}$ and $A_{2}$ are the asymptotes, $\log \left(x_{0}\right)$ is the reported $K_{\mathrm{d}}$, and $p$ is the Hill slope. To generate the activation curve for the fluid jet stimulation, the bundle position at the time of the peak current was used. Activation curves were fit with a double Boltzmann according to Equation 1.

Data were analyzed using jClamp, MATLAB (MathWorks), and Excel (Microsoft). Graphs were created using MATLAB, Origin 8.6, and Adobe Illustrator. The resting mechanosensitive current/maximum mechanosensitive current is $P_{\text {open }}$, in which we assume we can achieve a $P_{\text {open }}$ of $100 \%$. Mechanosensitive current is the difference between current values elicited from the maximal negative and maximal positive stimulation. Occasionally, the most negative current was identified during the return to rest after the positive stimulation.

Statistical analysis used Student's two-tailed $t$ tests from Excel (Microsoft), except when noted. All $p$ values presented used paired $t$ tests with comparisons within a cell and unpaired unequal variance tests across cell conditions. Significance ( $p$ values) is as follows: ${ }^{\star} p<0.05$, ${ }^{* *} p<0.01,{ }^{* *} p<0.001$, and ${ }^{* * * *} p<0.0001$. Data are presented as mean \pm SD unless otherwise noted.

\section{Results}

\section{Divalent specificity of extracellular $\mathrm{Ca}^{2+}$ effect on resting} $P_{\text {open }}$

Lowering extracellular $\mathrm{Ca}^{2+}$ increases $\mathrm{MET}$ channel resting $P_{\text {open }}$ (Fig. 2a, 3), identifying binding sites for $\mathrm{Ca}^{2+}$ that, when bound, lower the resting $P_{\text {open }}$. Lowering extracellular $\mathrm{Ca}^{2+}$ to $20 \mu \mathrm{M}$ increases the resting $P_{\text {open }}$ to near $50 \%$ regardless of internal $\mathrm{Ca}^{2+}$ concentration (Fig. 2). Internal solutions containing BAPTA, EGTA, $4 \mathrm{~mm}$ barium, or $1.4 \mathrm{~mm}$ Ca produced shifts of a similar degree, suggesting that the effector site was extracellular. The magnitude of the shift was variable, with 26 of 53 cells reaching $>40 \% P_{\text {open }}$ (Fig. 2b). The increase to near $50 \% P_{\text {open }}$ is consistent with other reports (Beurg et al., 2010; Johnson et al., 2011). To maximize stability, we tried a variety of perfusion methods. We used the Picospritzer III (Parker Hannifin) for local perfusion with pipette diameters of 3-15 $\mu \mathrm{m}$ placed 5-60 $\mu \mathrm{m}$ from the cell, as well as an apical perfusion with pipette diameters of 150-300 $\mu \mathrm{m}$ located $100-400 \mu \mathrm{m}$ from the cell. Every method produced scattered results, suggesting a biological origin. We chose to use the large apical perfusion method because this had the largest percentage of shifted cells. The results with $1 \mathrm{~mm}$ EGTA differ from a previous report (Johnson et al., 2011) but are in line with a recent report from the same group (Corns et al., 2014), attesting to the inherent variability within the measurements. We generated a dose-response curve of resting $P_{\text {open }}$ versus extracellular $\mathrm{Ca}^{2+}$ (Fig. 3). Fitting these data yielded an $\mathrm{IC}_{50}$ of $0.23 \pm 0.001 \mathrm{mM}$ (value $\pm \mathrm{SE}$ ) and a Hill slope of $2.8 \pm 0.01$ (value $\pm \mathrm{SE}$ ) with $p<0.002$ ( $F$ test). This dose-response curve is different from the blocking action of divalent ions on the MET channel $\left(\mathrm{IC}_{50}\right.$ of $1.1 \pm 0.03 \mathrm{~mm}$, Hill slope of $5.5 \pm 6.5$, value \pm SE; $p<0.007, F$ test; this $\mathrm{IC}_{50}$ is similar to that reported by Kim et al., 2013), arguing that we are probing a different site.

To determine whether the extracellular binding sites are specific to $\mathrm{Ca}^{2+}$, we tested other alkaline metal ions extracellularly (Fig. 4). We found that, in the presence of $2 \mathrm{mM} \mathrm{Ca}^{2+}, \mathrm{Sr}^{2+}$, or $\mathrm{Ba}^{2+}$, the resting $P_{\text {open }}$ remained low, but in the presence of $2 \mathrm{~mm}$ $\mathrm{Mg}^{2+}$, the resting $P_{\text {open }}$ increased significantly compared with $\mathrm{Ca}^{2+}, \mathrm{Sr}^{2+}$, or $\mathrm{Ba}^{2+}$ (unpaired $t$ test, $p<0.001$; Fig. 4). These data suggest that the extracellular binding sites are not highly 

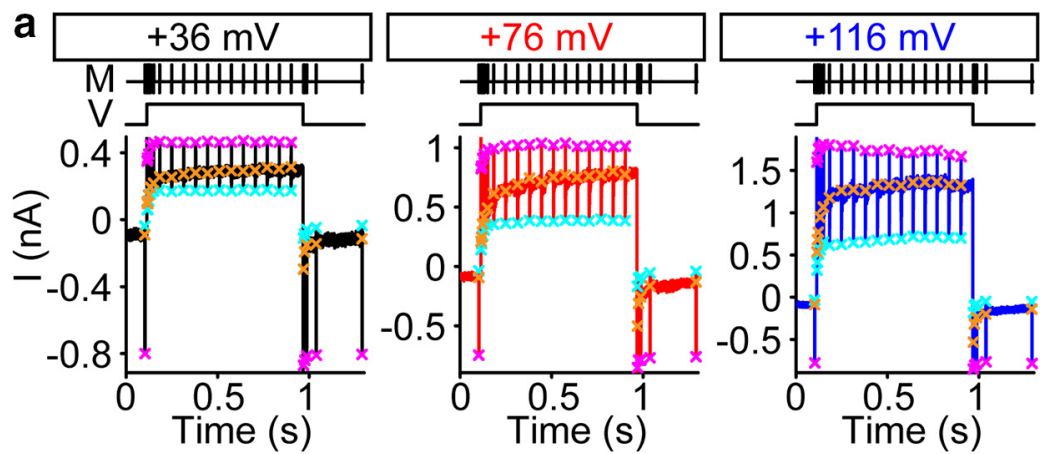

b

C
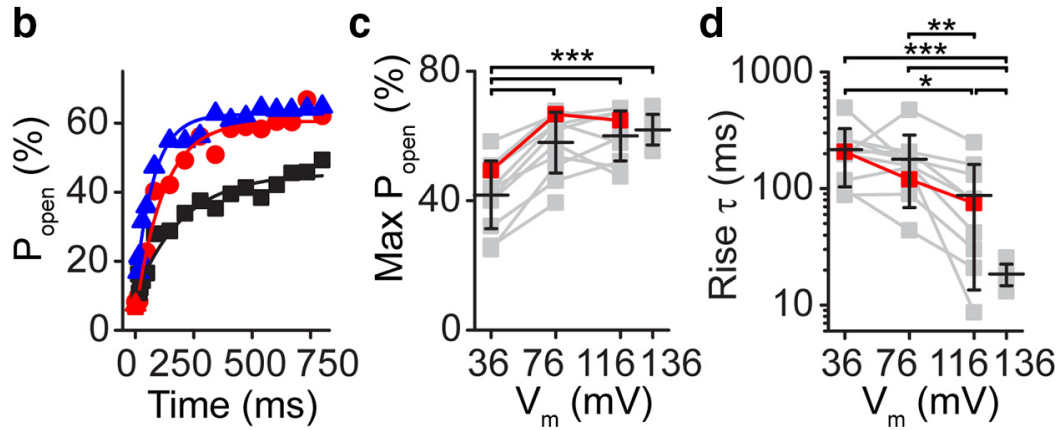

Figure 6. Voltage dependence of $P_{\text {open }}$ shift. $\boldsymbol{a}$, Depolarization to different potentials in an $\mathrm{OHC}$ shows the change in resting $P_{\text {open }}$ is dependent on potential. Plots are similar to those shown in Figure $5 a$ but for depolarization to 36,76 , and $116 \mathrm{mV}$. $\boldsymbol{b}$, Plot of the resting $P_{\text {open }}$ against depolarized time from the cell in $a$ shows the difference in kinetics and maximum $P_{\text {open }}$ for each potential. Colors correspond to $\boldsymbol{a}$. Solid lines are single-exponential fits to the data with $\tau=201 \mathrm{~ms}$ (black), $120 \mathrm{~ms}$ (red), and 80 ms (blue). c, Plot of the maximum $P_{\text {open }}$ reached for each potential. Lines connect data points from the same cell. For 36, 76, and 116 $\mathrm{mV}, n=11,11$, and 10, respectively. Depolarization to $136 \mathrm{mV}$ was performed in a separate set of cells $(n=11) . \boldsymbol{d}$, Plot of the single-exponential rise time of $P_{\text {open }}$ plotted for the different voltages, indicating a significant difference in rise time for 76, 116, and $136 \mathrm{mV}$, which all had the same max $P_{\text {open. }}$. Red symbols indicate the cell shown in $\boldsymbol{a}$ and $\boldsymbol{b}$. Black bars with error bars represent the mean \pm SD. M indicates the mechanical stimulus and V the voltage stimulus. ${ }^{*} p<0.05,{ }^{* *} p<0.01,{ }^{* * *} p<0.001$.

specific to $\mathrm{Ca}^{2+}$ and that $\mathrm{Mg}^{2+}$ has lower affinity and/or efficacy for these sites. This divalent profile suggests that we are examining global effects, such as surface charge (Träuble and Eibl, 1974).

The divalent profile is not typical of the common EF-hand motif for $\mathrm{Ca}^{2+}$ binding sites (Chao et al., 1984; Vyas et al., 1989) and suggests that our effects are dependent on ion size. We tested this hypothesis using two divalent transition metal ions $\left(\mathrm{Cd}^{2+}\right.$ and $\mathrm{Mn}^{2+}$ ) whose naked ionic radii (Persson, 2010) lie between $\mathrm{Ca}^{2+}$ and $\mathrm{Mg}^{2+}$. Consistent with the hypothesis, both of these ions produced intermediate shifts in $P_{\text {open }}$ (Fig. 4). Divalent ions whose radii were larger than $\mathrm{Ca}^{2+}$ produced a low resting $P_{\text {open }}$ $(<10 \%)$, whereas smaller divalent ions had lower affinities and/or efficacy (Fig. 4b, black). The variation of the response with ionic radius shows that we cannot apply classic Debye layer analysis in which the ions are treated as point charges (Israelachvili, 2011).

$\mathrm{Ca}^{2+}$ is a permeable blocker of the channel; thus, the conductance of the channel reduces with increasing $\mathrm{Ca}^{2+}$ concentration (Fig. 3; Crawford et al., 1991; Ricci and Fettiplace, 1998; Pan et al., 2012). To test whether the permeation site is different from the site affecting $P_{\text {open }}$, we analyzed divalent ion effects on peak current (Fig. $4 b$, blue). Normalizing the current amplitude by the control current in $2 \mathrm{mM} \mathrm{Ca}^{2+}$ and $\mathrm{Mg}^{2+}$, permeation had the opposite selectivity profile compared with the $P_{\text {open }} ; \mathrm{Ba}^{2+}$ and $\mathrm{Sr}^{2+}$ had less affinity as permeable blockers than $\mathrm{Ca}^{2+}$ or $\mathrm{Mg}^{2+}$. The peak current was not monotonic with naked ionic radius, in contrast to $P_{\text {open }}$. The inhibition of peak current also had a different $\mathrm{Ca}^{2+}$ affinity compared with the $P_{\text {open }}$ (Figs. 3, 4b). These differences suggest that the $P_{\text {open }}$ and conductance effector sites are distinct.

We previously used a high internal $\mathrm{Ca}^{2+}$ solution to argue for an extracellular site of divalent ion action (Peng et al., 2013). A confounding factor here could be that many processes use $\mathrm{Ca}^{2+}$ signaling so that the local concentration near open channels might be different from the concentration in the pipette as a result of local buffering and $\mathrm{Ca}^{2+}$ pumps. To decrease these potential $\mathrm{Ca}^{2+}$ regulation artifacts, we added $4 \mathrm{mM} \mathrm{Ba}^{2+}$ to the $1 \mathrm{~mm}$ BAPTA internal solution (Fig. $2 a$ ). $\mathrm{Ba}^{2+}$ keeps the resting $P_{\text {open }}$ low when applied extracellularly (Fig. 4), does not bind well to EFhand motifs (Chao et al., 1984), and exhibits slower extrusion by plasma membrane $\mathrm{Ca}^{2+}$ ATPase pumps (Thomas, 2009). Even with high intracellular $\mathrm{Ba}^{2+}$, resting $P_{\text {open }}$ increased in $20 \mu \mathrm{M}$ extracellular $\mathrm{Ca}^{2+}$ (Fig. 2), consistent with an extracellular site of divalent ion action.

\section{Voltage control of resting $\boldsymbol{P}_{\text {open }}$}

Voltage is known to modulate resting $P_{\text {open }}$ (Assad et al., 1989; Crawford et al., 1989; Zampini et al., 2011; Peng et al., 2013; Corns et al., 2014). To characterize how the $P_{\text {open }}$ changed with voltage, we delivered large negative and positive displacements at different time points during a prolonged depolarization (Fig. 5a,b). The maximum $P_{\text {open }}$ with depolarization to $76 \mathrm{mV}$ was $58 \pm 9 \%(n=26$; Fig. $5 d)$, consistent with other reports that use fluid jet stimuli (Zampini et al., 2011; Corns et al., 2014). With depolarization, $P_{\text {open }}$ rose to a maximum with a single-exponential time constant of $126 \pm 89$ $\mathrm{ms}(n=25$; Fig. $5 c, d)$. For short depolarizations as shown in Figure $6 a$, the recovery of $P_{\text {open }}$ at $-84 \mathrm{mV}$ had a time constant of $9.2 \pm 5.3 \mathrm{~ms}(n=25)$. As reported previously (Peng et al., 2013), $P_{\text {open }}$ also decreased slowly during a prolonged depolarization on a timescale $>1 \mathrm{~s}($ Fig. $5 a, c)$ because of unknown mechanisms that can bias the behavior of subsequent depolarizations. Here, we only investigated the increase in $P_{\text {open }}$, which was much slower than the $5.4 \pm 2.3 \mathrm{~ms}$ time constant reported in lower vertebrates (Ricci et al., 2000) and slower than any identified mammalian adaptation process (Stauffer and Holt, 2007; Waguespack et al., 2007).

We investigated the $\mathrm{Ca}^{2+}$ dependence of voltage modulation using $1.4 \mathrm{~mm}$ internal $\mathrm{Ca}^{2+}$. The maximum $P_{\text {open }}$ was slightly lower, but the time constant for rising to the maximum was slowed approximately threefold (Fig. $5 d$ ). To determine the specificity of divalent dependence, we repeated the experiment with a high $\mathrm{Ba}^{2+}$ internal solution and observed a similar shift in the resting $P_{\text {open }}$ as we did with high internal $\mathrm{Ca}^{2+}$ but with no effect on the rising time constant (Fig. $5 d$ ). These data are consistent with the internal $\mathrm{Ca}^{2+}$ modulating the depolarization effect.

We measured the voltage dependence of $P_{\text {open }}$ changes by depolarizing $\mathrm{OHCs}$ to 36, 76, and $116 \mathrm{mV}$ (Fig. 6). At $36 \mathrm{mV}$, $P_{\text {open }}$ did not increase as much as 76 or $116 \mathrm{mV}$ (Fig. $\left.6 b, c\right)$. The maximum resting $P_{\text {open }}$ at 76,116 , and $136 \mathrm{mV}$ was similar $(p=$ 0.48, single-factor ANOVA; Fig. $6 c$ ); however, the rising time 

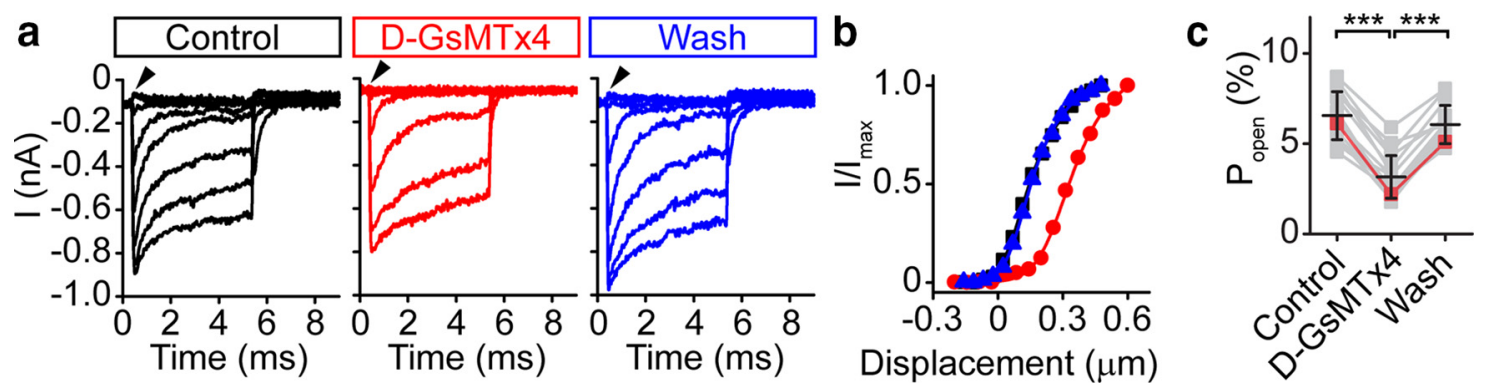

Figure 7. GsMTx4 acts as a gating modifier of MET channels. $\boldsymbol{a}$, Families of curves before (black), during application of $3 \mu \mathrm{M}$ GsMTx4 (red), and after washout (blue) shows the effect of D-GsMTx4 on MET. Note the decrease in resting current (arrowhead) to near zero in the presence of $\mathrm{D}-G \mathrm{SMTx} 4$, indicating a shift in the activation curve. Traces were post-filtered at $15 \mathrm{kHz}$. Mechanical stimulus used here is similar to those presented in Figure 2a, left traces. $\boldsymbol{b}$, Activation curves for each condition in a (control, black square; GsMTx4, red circle; wash, blue triangle) shows that D-GsMTx4 shifts the activation curve to the left, characteristic of a gating modifier. Data were fit with double Boltzmann curves. $c$, Resting $P_{\text {open }}$ decreases $52 \pm 12 \%$ ( $n=17$ ) in GsMTx4 and washes out, in line with a shift in the activation curve toward larger displacements. Lines connect data points for a given cell. Red points are from the cell presented in $\boldsymbol{a}$ and $\boldsymbol{b}$. Black bars with error bars represent the mean $\pm S D .{ }^{* * *} p<0.001$.

constants were significantly different (Fig. 6d). The increase in $P_{\text {open }}$ likely does not involve $\mathrm{Ca}^{2+}$ influx, because a change in driving force did not change the maximum $P_{\text {open }}$. However, the change in kinetics may support a modulatory role for intraciliary $\mathrm{Ca}^{2+}$.

\section{GsMTx4 modulates $P_{\text {open }}$}

The peptide GsMTx4, originally isolated from a tarantula venom, is a gating modifier of mechanically sensitive ion channels through modulation of lipid tension near the channel (Suchyna et al., 2000, 2004; Bowman et al., 2007; Nishizawa and Nishizawa, 2007; Posokhov et al., 2007a; Kamaraju et al., 2010). We tested the effects of GsMTx4 on MET channels using the D enantiomer of GsMTx4 (D-GsMTx4), a mirror image of the $\sim 3200$ Da natural peptide. At 2-3 $\mu \mathrm{M}, \mathrm{D}-\mathrm{GsMTx} 4$ shifted the activation curve toward larger displacements in the presence of $2 \mathrm{mM} \mathrm{Ca}^{2+}$ and $\mathrm{Mg}^{2+}\left(\Delta x_{0}=\right.$ $119 \pm 38 \mathrm{~nm}, n=17)$, and this effect was reversible (from control $\left|\Delta x_{0}\right|=14 \pm 11$ $\mathrm{nm}, n=15$; Figs. $7 a, b, 8 b)$. The shift from D-GsMTx4 occurred with a minimal decrease in the peak current (Fig. 8a), suggesting that GsMTx4 acts as a gating modifier, similar to its effect on stretch-activated channels in rat astrocytes and Piezol channels (Suchyna et al., 2004; Bae et al., 2011, 2013). The resting current, which is independent of probe placement, also decreased reversibly with GsMTx4 (Fig. 7a arrowheads, $c$ ). The $10-90 \%$ width of the $I-X$ curve increased slightly ( $11 \pm 20 \%, n=17$; Fig. 8 c). Overall, these data demonstrate that GsMTx4 is a gating modifier of the MET channel.

We tested whether the effect of GsMTx4 was stereospecific as an indication of its site of action being the lipid bilayer. Previous work argued for GsMTx4 affecting the lipid bilayer on stretch-activated channels because of bilayer partitioning (Posokhov et
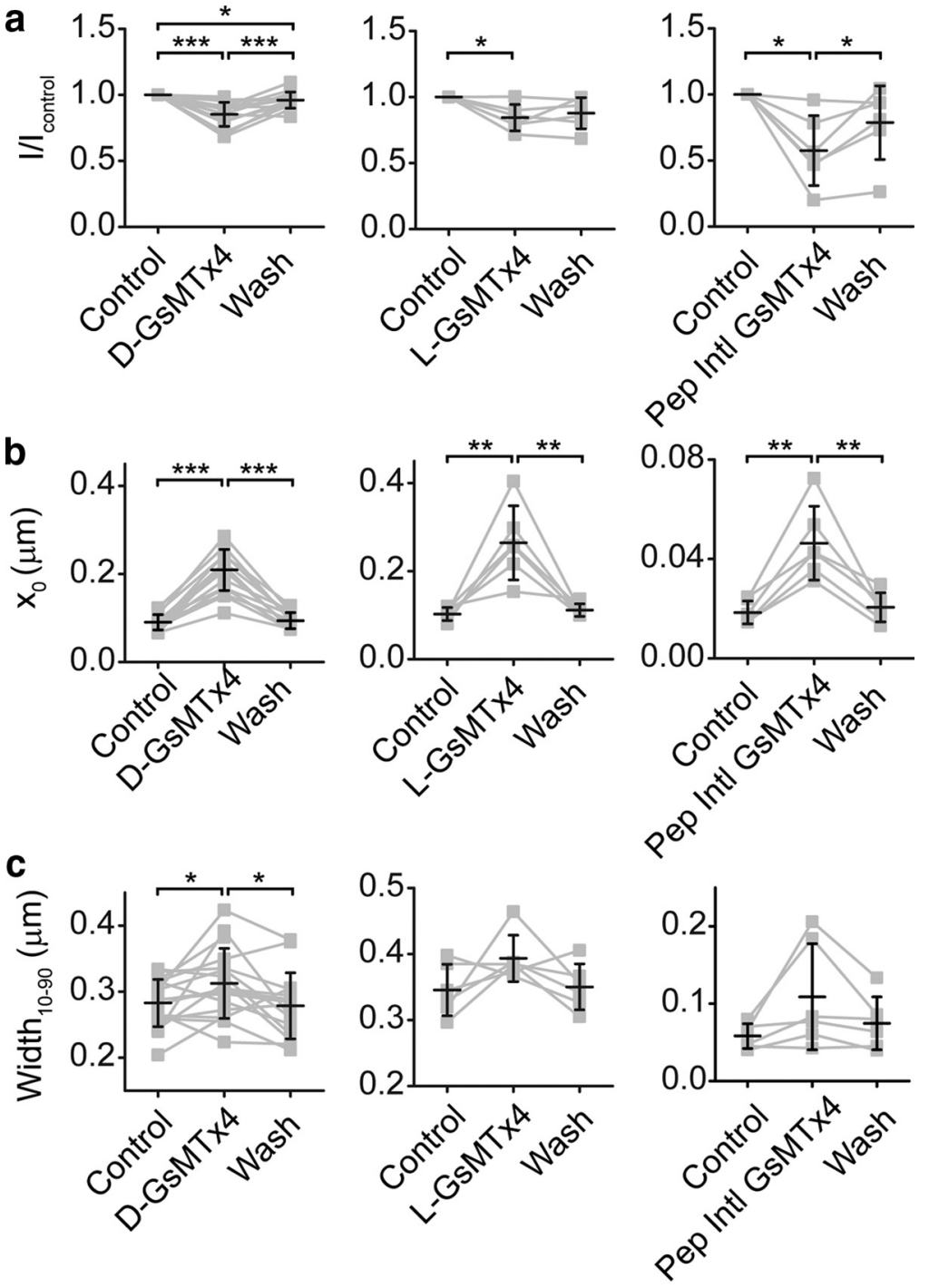

Figure 8. Parameters that characterize GSMTx4 effects. $\boldsymbol{a}$, Peak current decreases $15 \pm 9 \%(n=17)$ in the presence of D-GSMTx4 (left) and washed out. Similar results are observed in the presence of L-GSMTx4 (middle). With commercially obtained GSMTx4 from Peptides International, a larger block was observed (right). $\boldsymbol{b}$, All compounds observed a shift in the $x_{0}$ position in the presence of GsTMx4. c, Changes in the 10-90\% width of the activation curve is plotted for the various compounds. The Peptides International data were obtained using the fluid jet and therefore has lower observed widths and $x_{0}$ (attributable to the smaller width). This discrepancy in stimulation sizes has been seen by others as well (Kros et al., 2002; Beurg et al., 2014). Lines connect data points for a given cell and black error bars represent mean \pm SD. ${ }^{*} p<0.05,{ }^{* *} p<0.01,{ }^{* * *} p<0.001$. 

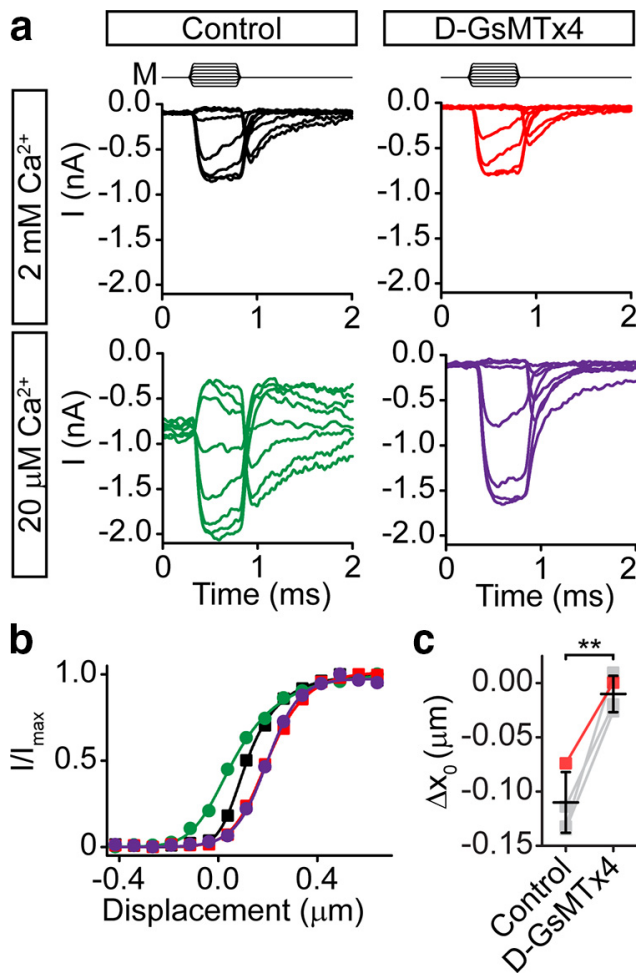

Figure 9. GsMTx4 blocks the extracellular $\mathrm{Ca}^{2+}$ effect. $\boldsymbol{a}$, Fast families of curves (no averaging) taken in the presence of control solution with $2 \mathrm{~mm} \mathrm{Ca}^{2+}$ and $2 \mathrm{~mm} \mathrm{Mg}^{2+}$ divalent ions (top row) and $20 \mu \mathrm{Ma}^{2+}$ (bottom row) extracellular solutions illustrate the effect of $2 \mu \mathrm{m}$ D-GSMTx4 in $2 \mathrm{~mm} \mathrm{Ca}^{2+}$ and $2 \mathrm{~mm} \mathrm{Mg}^{2+}$ (right top) and $20 \mu \mathrm{M} \mathrm{Ca}^{2+}$ extracellular solution (right bottom). $\boldsymbol{b}$, Activation curves for each condition (colors as indicated by traces in $\boldsymbol{a}$; squares are $2 \mathrm{~mm} \mathrm{Ca}^{2+}$ and $2 \mathrm{~mm} \mathrm{Mg}^{2+}$, and circles are $20 \mu \mathrm{m} \mathrm{Ca}{ }^{2+}$ ) show that the $20 \mu \mathrm{M} \mathrm{Ca}{ }^{2+}$ induced negative activation curve shift is abolished in the presence of D-GsMTX4. c, Summary of cells shows that D-GSMTx4 significantly decreases the shift in $x_{0}$ of the activation curve from $2 \mathrm{~mm} \mathrm{Ca}^{2+}$ and $2 \mathrm{~mm} \mathrm{Mg}^{2+}$ to $20 \mu \mathrm{M} \mathrm{Ca}{ }^{2+}$ extracellular solutions (93 $\pm 13 \%$, $n=4) . \Delta x_{0}=x_{0}{ }^{(20 \mu \mathrm{m} \mathrm{Ca})}-x_{0}{ }^{(2 \mathrm{~mm} \text { Ca })}$. Red points are from the cell presented in $\boldsymbol{a}$ and $\boldsymbol{b}$. Lines connect data points for a given cell and black error bars represent mean \pm SD. ${ }^{* *} p<0.01$.

al., 2007a,b) and similar efficacy of the L and D enantiomers (Suchyna et al., 2004). This argues against a stereospecific, chiral, binding site (e.g., lock and key mechanism). In hair cells, L-GsMTx4 had an efficacy $\left(\Delta x_{0}=162 \pm 91 \mathrm{~nm}, n=6\right.$; Fig. $\left.8 b\right)$ similar to D-GsMTx4, consistent with a lipid-based mode of action.

Previous work in hair cells reported two actions of GsMTx4: open channel blocking and gating modification (Beurg et al., 2014). We obtained GsMTx4 through collaboration with the inventors in which the peptide was assayed by mass spectrometry, circular dichroism spectroscopy, calorimetry, and HPLC (Oswald et al., 2002; Ostrow et al., 2003) and functionally on Piezol channels (Bae et al., 2011). To compare results from different suppliers, we also obtained a commercially available form of L-GsMTx4 (PCB-4393-s; Peptides International), which elicited a stronger open channel block closer to that reported previously (Beurg et al., 2014) than we observed with compounds obtained from our collaborator (Frederick Sachs, SUNY Buffalo, Buffalo, NY; Fig. 8a). There are apparently differences in structure associated with synthesis, purification, or storage of the peptide from different suppliers. However, we observed gating modifier activity as a shift in the set point of the activation curve with all compounds, as well as a slight increase in activation curve width (Fig. 8b,c).
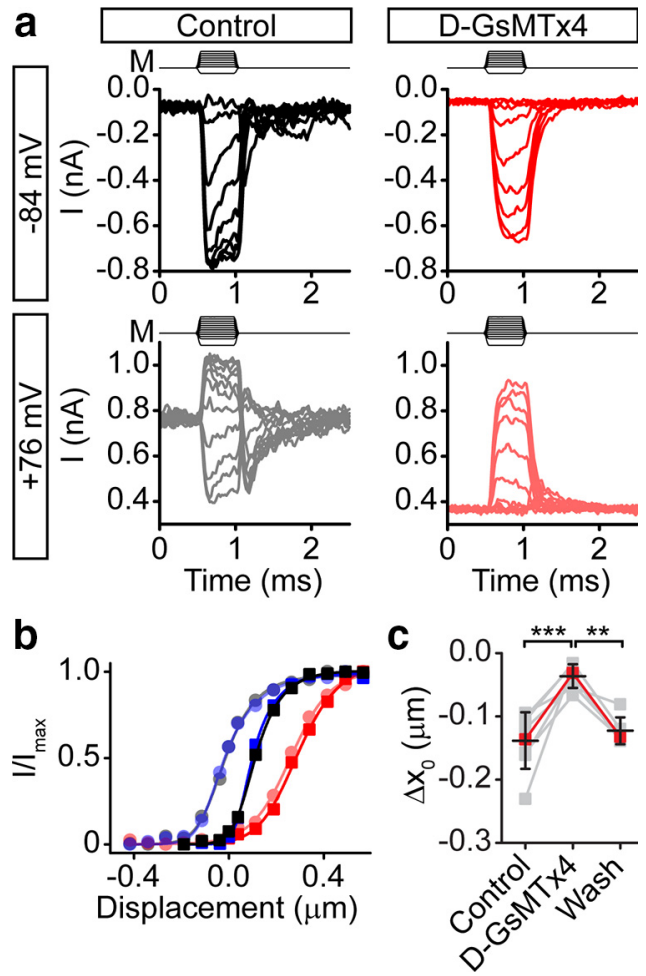

Figure 10. GsMTx4 inhibits voltage modulation. $\boldsymbol{a}$, Fast families of curves (no averaging) taken before depolarization (top left) and $\sim 500 \mathrm{~ms}$ after depolarization to $76 \mathrm{mV}$ (bottom left) illustrate the effect of $2 \mu \mathrm{m}$ D-GsMTx4 (right top) on the activation curve shift attributable to depolarization (right bottom). $\boldsymbol{b}$, Activation curves show that the $x_{0}$ shift attributable to depolarization in control solutions (black trace, $-84 \mathrm{mV}$; gray trace, $76 \mathrm{mV}$ ) is blocked with D-GsMTx4 (red trace, $-84 \mathrm{mV}$; light red trace, $76 \mathrm{mV}$ ), and this effect can be washed out (blue trace, $-84 \mathrm{mV}$; light blue trace, $76 \mathrm{mV}$ ). c, Summary of cells showing that D-GsMTx4 significantly reduced the change in $x_{0}$ attributable to depolarization $(71 \pm 17 \%, n=8)$ and was washed out ( $4 \pm 13 \%$ decrease from control, $n=6) \cdot \Delta x_{0}=x_{0}{ }^{(76 \mathrm{mV})}-x_{0}{ }^{(-84 \mathrm{mV})}$. Red points are from the cell presented in $\boldsymbol{a}$ and $\boldsymbol{b}$. Lines connect data points for a given cell and black error bars represent mean \pm SD. ${ }^{* *} p<0.01,{ }^{* * *} p<0.001$.

GsMTx4 differentially modulates $\boldsymbol{P}_{\text {open }}$ and adaptation

The data in Figure $7 a$ suggest that GsMTx 4 affects resting $P_{\text {open }}$ without a significant change in the percentage of adaptation. To determine whether $P_{\text {open }}$ modulation and fast adaptation are indeed two separate mechanisms, we tested whether GsMTx4 affects $P_{\text {open }}$ modulation differentially from fast adaptation. Because GsMTx4 shifts the activation curves to larger displacements, changes in resting $P_{\text {open }}$ could appear to minimize the underlying activation curve shifts caused by lowering extracellular $\mathrm{Ca}^{2+}$. To reduce this potential artifact, we generated full activation curves in each condition to monitor shifts in the activation curves. We found that the negative activation curve shift in $20 \mu \mathrm{M}$ $\mathrm{Ca}^{2+}$ of $114 \pm 28 \mathrm{~nm}(n=4$; Fig. $9 a, b$, black to green traces $)$ decreased by $93 \pm 13 \%$ to $9 \pm 16 \mathrm{~nm}(n=4)$ in the presence of GsMTx4 (Fig. 9). Thus, GsMTx4 inhibits the modulation of $P_{\text {open }}$ by extracellular $\mathrm{Ca}^{2+}$.

We next tested whether GsMTx4 affects the voltage regulation of $P_{\text {open }}$ using full activation curves before depolarization and $\sim 500 \mathrm{~ms}$ after depolarization to $76 \mathrm{mV}$. Again, we found that the negative activation curve shift attributable to depolarization (Fig. 10a,b, black to gray traces) was decreased by GsMTx4 (Fig. 10a, $b$, red to light red traces). The inhibition of the voltage effect was reversible (Fig. 10b, blue to light blue traces). In four cells, we depolarized in $20 \mu \mathrm{M}$ extracellular $\mathrm{Ca}^{2+}$ with $2 \mu \mathrm{M}$ GsMTx4 and found that depolarization also had little effect. In all 

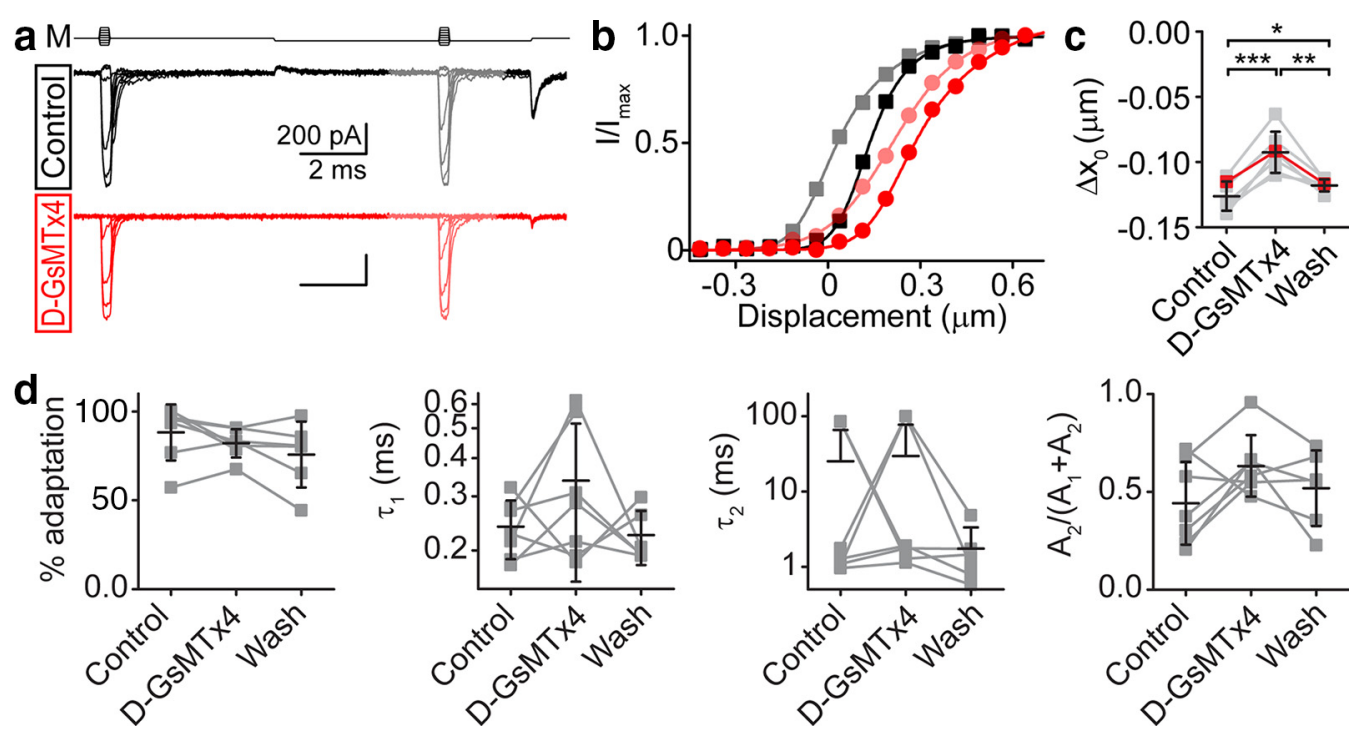

Figure 11. GsMTX4 effect on adaptation is minimal. $\boldsymbol{a}$, Two-pulse experiments with a negative displacement adaptation step investigate D-GsMTx4 effects on adaptation. Activation curves after the adaptation step are colored lighter. M indicates the mechanical stimulus waveform. $\boldsymbol{b}$, Activation curves for before (darker traces) and after (lighter traces) the adaptation step show that the adaptation shift is slightly decreased in the presence of $3 \mu \mathrm{M} \mathrm{D}$-GSMTx4 (red and light red circles) compared with control (black and gray squares). c, Summary of cells shows the adaptation shift is decreased by $27 \pm 9 \%(n=7) . \Delta x_{0}=x_{0}$ (after) $-x_{0}{ }^{\text {(before) }}$. Red points are from the cell presented in $\boldsymbol{a}$ and $\boldsymbol{b} .{ }^{*} p<0.05,{ }^{* *} p<0.01,{ }^{* * *} p<0.001$. $\boldsymbol{d}$, No significant differences were found in adaptation properties in the presence of D-GSMTX4 from the analysis of step responses like that seen in Figure $7 a$. Percentage adaptation was calculated as $\left(1-I_{\text {steady state }} / I_{\text {peak }}\right) \times 100$. Double-exponential fits of the $\sim 50 \%$ peak current traces do not reveal significant differences in the time constants of adaptation ( $\tau_{1}$ is the faster time constant and $\tau_{2}$ is the slower time constant) or the percentage contribution of $\tau_{2}\left[A_{2} /\left(A_{1}+A_{2}\right)\right]$. Lines connect data points for a given cell and black error bars represent mean $\pm S D$.

cells tested, the depolarization-induced negative shift was inhibited $71 \pm 17 \%(n=8)$ in the presence of GsMTx4 (Fig. 10c). These results are in line with early studies by Marcotti et al. (2002), who showed that $1 \mu \mathrm{M}$ GsMTx4 caused reduced $P_{\text {open }}$ at depolarized potentials (Palmer and Rosen, 2002). Thus, GsMTx4 can inhibit both extracellular $\mathrm{Ca}^{2+}$ and voltage modulation of $P_{\text {open }}$.

Finally, we examined GsMTx4 effects on fast adaptation to assess the independence of adaptation from $P_{\text {open }}$ modulation. The rates and percentage of adaptation in the presence of GsMTx4 were not significantly different from controls (Fig. 11d). We also investigated the effect of GsMTx4 on adaptation using a two-pulse protocol (Fig. 11a). Because lowering extracellular $\mathrm{Ca}^{2+}$ or depolarization caused a leftward activation curve shift of 100-150 nm, we mimicked this shift for adaptation by using a negative adaptation step of $\sim 150 \mathrm{~nm}$. The negative adaptation step served a second purpose of decreasing the likelihood of hair bundle damage by overstimulation because, with GsMTx4, the activation curves are already right shifted. In the two-pulse protocol, control activation curves shifted $-126 \pm 11 \mathrm{~nm}(n=8$; Fig. $11 b, c)$. With GsMTx4, the shift decreased $27 \pm 9 \%$ to $-93 \pm$ $16 \mathrm{~nm}(n=8$; Fig. $11 b, c)$. This effect could be partially washed out in $2-7 \min (118 \pm 5 \mathrm{~nm}, n=8$; Fig. $11 c)$. Thus, using comparable activation curve perturbations, the effect of GsMTx4 on adaptation is small and is very different from the near abolition of the effects of extracellular $\mathrm{Ca}^{2+}$ and voltage. Our data indicate that $P_{\text {open }}$ modulation by divalents and voltage is a process separate from fast adaptation. Extracellular divalent ions, voltage, and GsMTx 4 affect the newly identified $P_{\text {open }}$ modulation mechanism in a manner consistent with a lipid-based mechanism.

\section{Discussion}

We investigated mechanisms controlling the resting $P_{\text {open }}$ of the MET channel in mammalian auditory hair cells, extending our previous work that identified an extracellular binding site. Here, we demonstrate that these sites are not $\mathrm{Ca}^{2+}$ specific.
We also show that the depolarization-induced increase in $P_{\text {open }}$ has a voltage dependence in which the amount of depolarization affects the rate of $P_{\text {open }}$ rise. Using GsMTx4, we inhibited $P_{\text {open }}$ modulation with minor effects on the fast component of adaptation, confirming the existence of a second mechanism of $P_{\text {open }}$ modulation. Finally, our results with GsMTx4 are consistent with a mechanism in which $P_{\text {open }}$ modulation occurs through local lipid stress surrounding the MET channel.

\section{Separation of $\boldsymbol{P}_{\text {open }}$ modulation and adaptation}

Classically, adaptation is what sets the operating point of the MET channel (Fettiplace and Kim, 2014). There are multiple modes of adaptation with reported time constants on the order of hundreds of microseconds, single milliseconds, and tens of milliseconds in mammalian auditory hair cells, with the slowest time constant purported to be slow myosin motor driven adaptation (Holt et al., 2002; Kennedy et al., 2003; Stauffer and Holt, 2007; Waguespack et al., 2007; Peng et al., 2013; Corns et al., 2014). Historically, $P_{\text {open }}$ changes associated with membrane potential or extracellular $\mathrm{Ca}^{2+}$ were considered a manifestation of adaptation and were used to argue that adaptation is $\mathrm{Ca}^{2+}$ dependent (Crawford et al., 1991; Assad and Corey, 1992; Corns et al., 2014; Fettiplace and Kim, 2014). Our new data demonstrate that, in mammalian cochlear hair cells, $P_{\text {open }}$ modulation can occur independently of fast adaptation. This is supported by the inhibition of $P_{\text {open }}$ modulation, whereas fast adaptation remains intact in the presence of GsMTx4. Our experiments used $5 \mathrm{~ms}$ pulses, which rules out adaptation processes in the hundreds of microseconds to single millisecond range. This process is also likely not associated with the slowest time constant of adaptation, because the rising $P_{\text {open }}$ time constant attributable to depolarization is an order of magnitude slower (Fig. 5). Previously, data from the bullfrog saccule showed a divalent ion sensitivity similar to calmodulin; thus, a calmodulin-mediated regulation of myosin motors was proposed (Corey and Hudspeth, 1983; Chao et al., 1984; 


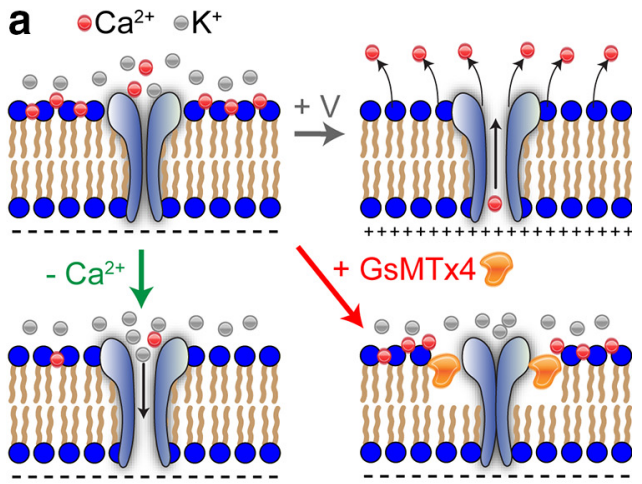

b
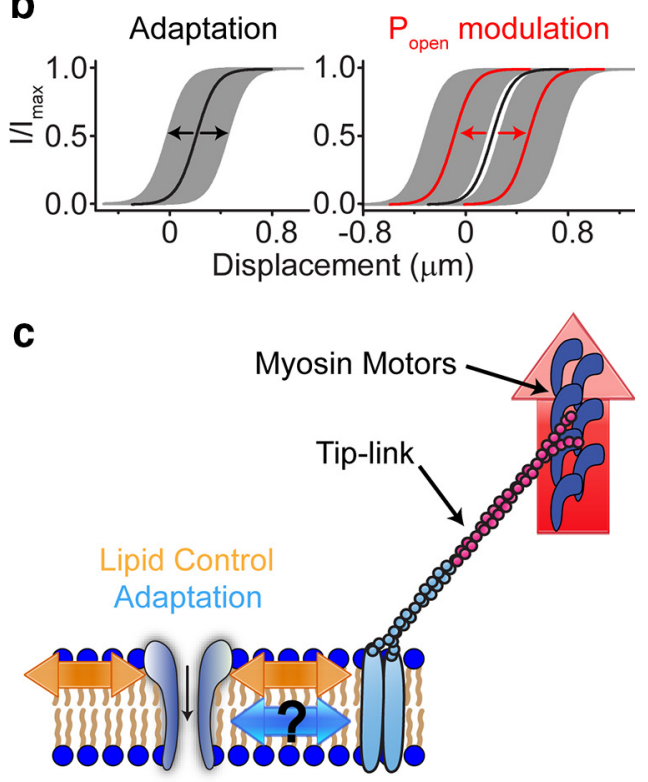

Figure 12. Schematic drawing of the mechanisms involved in MET channel modulation. $\boldsymbol{a}$, Top left, $\mathrm{Ca}^{2+}$ is normally adsorbed into the outer leaflet of the membrane, causing decreased force sensed by the channel, leading to a low $P_{\text {open }}$. Top right, During depolarization, $\mathrm{Ca}^{2+}$ ions are repelled from the membrane, causing increased force sensed by the channel leading to a higher $P_{\text {open }}$. Bottom left, Decreasing the extracellular divalent ions from the extracellular side decreases the adsorbed $\mathrm{Ca}^{2+}$ ions, leading to increased force sensed by the channel (higher $P_{\text {open }}$ ). Bottom right, GsMTx4 inserts into the outer leaflet, decreases force sensed by the channel (lower $\left.P_{\text {open }}\right)$, and shunts any other lipid effects. $\boldsymbol{b}$, Illustration of two independent mechanisms that control the midpoint of the activation curve. Adaptation controls the position (shaded gray regions) around the set point (black line), whereas extracellular divalent ions and voltage shift the set point (red lines).c, Schematic drawing of the three mechanisms that control channel $P_{\text {open }}$. Red arrow represents myosin motors that provide constant tension. Blue arrows represent adaptation, which has an unknown mechanism. Orange arrows represent the lipid modulation of the channel resting $P_{\text {open }}$.

Hacohen et al., 1989; Gillespie and Cyr, 2004). However, this hypothesis is not supported in mammalian hair cells because the divalent specificity does not match that of calmodulin (Fig. 4) and the divalent effect is extracellular (Fig. 2), further suggesting that $P_{\text {open }}$ control is not associated with the slowest time constant of adaptation (motor adaptation). With this new mechanism of $P_{\text {open }}$ modulation separate from adaptation, previous data need reexamination because the underlying assumption that only adaptation modulates $P_{\text {open }}$ is no longer valid.

\section{Implications for adaptation}

Recently, there is much debate about the mechanisms of adaptation. In mammalian auditory hair cells, our group has shown $\mathrm{Ca}^{2+}$-independent adaptation (Peng et al., 2013), whereas others have reported $\mathrm{Ca}^{2+}$-dependent adaptation (Corns et al., 2014, 2016; Beurg et al., 2015). The major difference in the two approaches is in the mode of stimulation (stiff probe vs fluid jet), each having merits and caveats (Nam et al., 2015). The $500 \mu$ s rise time of the fluid jet precludes accurately assessing the fastest adaptation, which is argued to be $\mathrm{Ca}^{2+}$ independent (Peng et al., 2013). Present work suggests that fast adaptation and classical motor adaptation is separate from $P_{\text {open }}$ modulation by extracellular $\mathrm{Ca}^{2+}$ and voltage. Therefore, set point changes using these manipulations to support $\mathrm{Ca}^{2+}$-dependent adaptation requires reinterpretation. However, still unexplained are the differences with stimulus modality seen in two-pulse experiments and time-dependent current decay, which require additional exploration.

\section{Voltage modulation of mechanotransduction}

The data suggest an effect of intracellular $\mathrm{Ca}^{2+}$ that is specific to $\mathrm{Ca}^{2+}$ as seen by the kinetic changes with various internal solutions (Fig. $5 d$ ). The change in kinetics attributable to depolarization (Fig. $6 d$ ) suggests a mechanism that lies within the electric field of the membrane. However, we cannot rule out the possibility of a $\mathrm{Ca}^{2+}$ dependence on intracellular $\mathrm{Ca}^{2+}$ concentration, because stereocilia $\mathrm{Ca}^{2+}$ concentrations may differ from cytoplasmic $\mathrm{Ca}^{2+}$ concentrations (Delling et al., 2013; Beurg et al., 2015). Based on our results with high internal $\mathrm{Ca}^{2+}, \mathrm{Ca}^{2+}$ modulates the change in $P_{\text {open }}$ attributable to voltage.

\section{Unifying mechanism of resting $P_{\text {open }}$ control}

How do our manipulations (divalent ions, voltage, and GsMTx4) affect the channel? The manipulations could affect the lipid-channel interface to change resting forces applied to the channel, the energy for different conformational states, or the energy barrier between channel states (Andersen et al., 1999). GsMTx4 affects the energy landscape by embedding in the membrane, altering local stress, and increasing the energy required to reach the open state (Andersen et al., 1999; Sachs, 2010; Nishizawa et al., 2015). The shift in the activation curve set point and the increase in the activation curve width support this model of GsMTx4 action (Fig. 8). Thus, GsMTx4 alters the force translation to the MET channel. The fact that GsMTx 4 can abolish the effects of voltage and divalent ions (Figs. 9, 10) suggests that GsMTx4, when inserted into the lipid, dominates the interaction with the channel. Voltage and divalent ions can also create mechanical changes in the lipid (Akinlaja and Sachs, 1998; Beyder and Sachs, 2009). These effects of voltage and divalent ions may be acting through the electric field in the membrane (Fig. 12a; Zhang et al., 2001). For negative surface potentials, decreasing extracellular divalent ions changes the membrane field similar to depolarization. Mobile counter-ions along the membrane surface repel each other laterally, creating membrane tension (the Lippmann effect; Petrov and Sachs, 2002; Sachs et al., 2009) or the converse flexoelectric effect (Todorov et al., 1994; Petrov and Sachs, 2002; Beyder and Sachs, 2009; Harland et al., 2010).

Multivalent ions can change membrane mechanical properties by binding between adjacent lipids (Ito and Onishi, 1974; Onishi and Ito, 1974; Träuble and Eibl, 1974; Jacobson and Papahadjopoulos, 1975; Lösche and Möhwald, 1989; Ermakov et al., 2010). This can be a large effect producing lipid phase separations that may exhibit the divalent ion specificity as we observed (Fig. 4; Ito and Onishi, 1974). Forces at the lipid-channel interface affect mechanosensitive channels 
(Perozo et al., 2002; Sukharev and Sachs, 2012). The line tension between the channel and the lipids (Markin and Sachs, 2004; Wiggins and Phillips, 2005) is a component of the work the channel must perform to open (Anishkin and Kung, 2013). Soft lipids would provide a smaller energy barrier to overcome so that a decrease in extracellular $\mathrm{Ca}^{2+}$ that reduces the lipid stiffness makes it easier for channels to open.

\section{Alternative possibilities}

Our results are consistent with a common pathway involving the lipid (Figs. 9, 10), but there are other potential mechanisms. Changes in extracellular $\mathrm{Ca}^{2+}$ will change the local electrostatics and perhaps affect proteins that are located near the channel, such as Tmhs, Tmie, Tmc1, Tmc2, or the tip-link (Ahmed et al., 2006; Kazmierczak et al., 2007; Kawashima et al., 2011; Xiong et al., 2012; Beurg et al., 2014; Marcotti et al., 2014; Zhao et al., 2014). However, the voltage sensitivity suggests that tip-links are not involved because there are no voltage drops on the extracellular links (Ahmed et al., 2006; Kazmierczak et al., 2007). Another potential mechanism could be an effect on a slower adaptation process that we have not directly tested.

\section{Implications for hair cell MET}

In the mammalian auditory system, three separate mechanisms likely modulate the MET channel (Fig. 12c). The first is a motor, likely Myosin VIIa or Ic, that climbs along the sides of stereocilia to generate tension in the tip-link (Holt et al., 2002; Kros et al., 2002; Stauffer et al., 2005; Grati and Kachar, 2011). This motor does not represent fast adaptation as classically defined with a stiff probe and could be the $\mathrm{Ca}^{2+}$-dependent mechanism observed by others (Corns et al., 2014), in which case it would be a form of slow adaptation that may be inhibited by the mass of the stiff probe. Fast adaptation allows the system to increase its dynamic range by reducing low-frequency gain (Fig. 12b). This mechanism acts to decrease the net force applied to the channel, but it is not solely responsible for setting the resting state of the channel as thought previously. The lipid modulation described here is a new mechanism that clearly plays a significant role in setting the resting $P_{\text {open }}$ (Fig. 12). This system reduces the chance of saturating the fast adaptation mechanism and thus allows it to maintain its role as a high-pass filter. In the cochlea, this mechanism would probably not dynamically regulate the resting $P_{\text {open }}$ but would rather set the resting $P_{\text {open }}$ in the steady state to position the MET channel in the range of greatest sensitivity. Our data support a new model for regulation of the MET activation curve in which a molecular motor provides a constant tip-link tension, adaptation provides fast dynamic adjustment of force applied to the channel (AC response), and $\mathrm{Ca}^{2+}$ ion concentration coupled with membrane potential modulates the resting $P_{\text {open }}$ via a lipid-based mechanism (DC response).

\section{References}

Ahmed ZM, Goodyear R, Riazuddin S, Lagziel A, Legan PK, Behra M, Burgess SM, Lilley KS, Wilcox ER, Griffith AJ, Frolenkov GI, Belyantseva IA, Richardson GP, Friedman TB (2006) The tip-link antigen, a protein associated with the transduction complex of sensory hair cells, is protocadherin-15. J Neurosci 26:7022-7034. CrossRef Medline

Akinlaja J, Sachs F (1998) The breakdown of cell membranes by electrical and mechanical stress. Biophys J 75:247-254. CrossRef Medline

Andersen OS, Nielsen C, Maer AM, Lundbaek JA, Goulian M, Koeppe RE 2nd (1999) Ion channels as tools to monitor lipid bilayer-membrane protein interactions: gramicidin channels as molecular force transducers. Methods Enzymol 294:208-224. CrossRef Medline
Anishkin A, Kung C (2013) Stiffened lipid platforms at molecular force foci. Proc Natl Acad Sci U S A 110:4886-4892. CrossRef Medline

Assad JA, Corey DP (1992) An active motor model for adaptation by vertebrate hair cells. J Neurosci 12:3291-3309. Medline

Assad JA, Hacohen N, Corey DP (1989) Voltage dependence of adaptation and active bundle movement in bullfrog saccular hair cells. Proc Natl Acad Sci U S A 86:2918-2922. CrossRef Medline

Bae C, Sachs F, Gottlieb PA (2011) The mechanosensitive ion channel Piezo1 is inhibited by the peptide GsMTx4. Biochemistry 50:6295-6300. CrossRef Medline

Bae C, Gottlieb PA, Sachs F (2013) Human PIEZO1: removing inactivation. Biophys J 105:880-886. CrossRef Medline

Beurg M, Fettiplace R, Nam JH, Ricci AJ (2009) Localization of inner hair cell mechanotransducer channels using high-speed calcium imaging. Nat Neurosci 12:553-558. CrossRef Medline

Beurg M, Nam JH, Chen Q, Fettiplace R (2010) Calcium balance and mechanotransduction in rat cochlear hair cells. J Neurophysiol 104: 18-34. CrossRef Medline

Beurg M, Kim KX, Fettiplace R (2014) Conductance and block of hair-cell mechanotransducer channels in transmembrane channel-like protein mutants. J Gen Physiol 144:55-69. CrossRef Medline

Beurg M, Goldring AC, Fettiplace R (2015) The effects of Tmc1 Beethoven mutation on mechanotransducer channel function in cochlear hair cells. J Gen Physiol 146:233-243. CrossRef Medline

Beyder A, Sachs F (2009) Electromechanical coupling in the membranes of Shaker-transfected HEK cells. Proc Natl Acad Sci U S A 106:6626-6631. CrossRef Medline

Bialek W (1987) Physical limits to sensation and perception. Annu Rev Biophys Biophys Chem 16:455-478. CrossRef Medline

Bowman CL, Gottlieb PA, Suchyna TM, Murphy YK, Sachs F (2007) Mechanosensitive ion channels and the peptide inhibitor GsMTx-4: history, properties, mechanisms and pharmacology. Toxicon 49:249-270. CrossRef Medline

Chao SH, Suzuki Y, Zysk JR, Cheung WY (1984) Activation of calmodulin by various metal cations as a function of ionic radius. Mol Pharmacol 26:75-82. Medline

Corey DP, Hudspeth AJ (1983) Kinetics of the receptor current in bullfrog saccular hair cells. J Neurosci 3:962-976. Medline

Corns LF, Johnson SL, Kros CJ, Marcotti W (2014) Calcium entry into stereocilia drives adaptation of the mechanoelectrical transducer current of mammalian cochlear hair cells. Proc Natl Acad Sci U S A 111: 14918-14923. CrossRef Medline

Corns LF, Johnson SL, Kros CJ, Marcotti W (2016) Tmcl point mutation affects $\mathrm{Ca}^{2+}$ sensitivity and block by dihydrostreptomycin of the mechanoelectrical transducer current of mouse outer hair cells. J Neurosci 36: 336-349. CrossRef Medline

Crawford AC, Evans MG, Fettiplace R (1989) Activation and adaptation of transducer currents in turtle hair cells. J Physiol 419:405-434. CrossRef Medline

Crawford AC, Evans MG, Fettiplace R (1991) The actions of calcium on the mechano-electrical transducer current of turtle hair cells. J Physiol 434: 369-398. CrossRef Medline

Delling M, DeCaen PG, Doerner JF, Febvay S, Clapham DE (2013) Primary cilia are specialized calcium signalling organelles. Nature 504:311-314. CrossRef Medline

Eatock RA, Corey DP, Hudspeth AJ (1987) Adaptation of mechanoelectrical transduction in hair cells of the bullfrog's sacculus. J Neurosci 7:2821-2836. Medline

Ermakov YA, Kamaraju K, Sengupta K, Sukharev S (2010) Gadolinium ions block mechanosensitive channels by altering the packing and lateral pressure of anionic lipids. Biophys J 98:1018-1027. CrossRef Medline

Farris HE, Wells GB, Ricci AJ (2006) Steady-state adaptation of mechanotransduction modulates the resting potential of auditory hair cells, providing an assay for endolymph $\left[\mathrm{Ca}^{2+}\right]$. J Neurosci 26:12526-12536. CrossRef Medline

Fettiplace R, Kim KX (2014) The physiology of mechanoelectrical transduction channels in hearing. Physiol Rev 94:951-986. CrossRef Medline

Gillespie PG, Cyr JL (2004) Myosin-1c, the hair cell's adaptation motor. Annu Rev Physiol 66:521-545. CrossRef Medline

Grati M, Kachar B (2011) Myosin VIIa and sans localization at stereocilia upper tip-link density implicates these Usher syndrome proteins in 
mechanotransduction. Proc Natl Acad Sci U S A 108:11476-11481. CrossRef Medline

Hacohen N, Assad JA, Smith WJ, Corey DP (1989) Regulation of tension on hair-cell transduction channels: displacement and calcium dependence. J Neurosci 9:3988-3997. Medline

Harland B, Brownell WE, Spector AA, Sun SX (2010) Voltage-induced bending and electromechanical coupling in lipid bilayers. Phys Rev E Stat Nonlin Soft Matter Phys 81:031907. CrossRef Medline

Holt JR, Gillespie SK, Provance DW, Shah K, Shokat KM, Corey DP, Mercer JA, Gillespie PG (2002) A chemical-genetic strategy implicates myosin-1c in adaptation by hair cells. Cell 108:371-381. CrossRef Medline

Hudspeth AJ, Corey DP (1977) Sensitivity, polarity, and conductance change in the response of vertebrate hair cells to controlled mechanical stimuli. Proc Natl Acad Sci U S A 74:2407-2411. CrossRef Medline

Israelachvili JN (2011) Intermolecular and surface forces, Ed 3. Burlington, MA: Academic.

Ito T, Onishi S (1974) $\mathrm{Ca}^{2+}$-induced lateral phase separations in phosphatic acid-phosphatidylcholine membranes. Biochim Biophys Acta 352: 29-37. CrossRef Medline

Jacobson K, Papahadjopoulos D (1975) Phase-transitions and phase separations in phospholipid membranes induced by changes in temperature, $\mathrm{pH}$, and concentration of bivalent-cations. Biochemistry 14:152-161. CrossRef Medline

Johnson SL, Beurg M, Marcotti W, Fettiplace R (2011) Prestin-driven cochlear amplification is not limited by the outer hair cell membrane time constant. Neuron 70:1143-1154. CrossRef Medline

Kamaraju K, Gottlieb PA, Sachs F, Sukharev S (2010) Effects of GsMTx4 on bacterial mechanosensitive channels in inside-out patches from giant spheroplasts. Biophys J 99:2870-2878. CrossRef Medline

Kawashima Y, Géléoc GS, Kurima K, Labay V, Lelli A, Asai Y, Makishima T, Wu DK, Della Santina CC, Holt JR, Griffith AJ (2011) Mechanotransduction in mouse inner ear hair cells requires transmembrane channellike genes. J Clin Invest 121:4796-4809. CrossRef Medline

Kazmierczak P, Sakaguchi H, Tokita J, Wilson-Kubalek EM, Milligan RA, Müller U, Kachar B (2007) Cadherin 23 and protocadherin 15 interact to form tip-link filaments in sensory hair cells. Nature 449:87-91. CrossRef Medline

Kennedy HJ, Evans MG, Crawford AC, Fettiplace R (2003) Fast adaptation of mechanoelectrical transducer channels in mammalian cochlear hair cells. Nat Neurosci 6:832-836. CrossRef Medline

Kim KX, Beurg M, Hackney CM, Furness DN, Mahendrasingam S, Fettiplace R (2013) The role of transmembrane channel-like proteins in the operation of hair cell mechanotransducer channels. J Gen Physiol 142: 493-505. CrossRef Medline

Kros CJ, Marcotti W, van Netten SM, Self TJ, Libby RT, Brown SD, Richardson GP, Steel KP (2002) Reduced climbing and increased slipping adaptation in cochlear hair cells of mice with Myo7a mutations. Nat Neurosci 5:41-47. CrossRef Medline

Lösche M, Möhwald H (1989) Electrostatic interactions in phospholipid membranes: II. Influence of divalent ions on monolayer structure. J Colloid Interf Sci 131:56-67. CrossRef

Marcotti W, Sachs F, Ashmore JF, Kros CJ (2002) Effect of a peptide tarantula toxin on mechano-transduction in neonatal mouse cochlear hair cells. Int J Audiol 41:231.

Marcotti W, Corns LF, Desmonds T, Kirkwood NK, Richardson GP, Kros CJ (2014) Transduction without tip links in cochlear hair cells is mediated by ion channels with permeation properties distinct from those of the mechano-electrical transducer channel. J Neurosci 34:5505-5514. CrossRef Medline

Markin VS, Sachs F (2004) Thermodynamics of mechanosensitivity. Phys Biol 1:110-124. CrossRef Medline

Nam JH, Peng AW, Ricci AJ (2015) Underestimated sensitivity of mammalian cochlear hair cells due to splay between stereociliary columns. Biophys J 108:2633-2647. CrossRef Medline

Nishizawa K, Nishizawa M, Gnanasambandam R, Sachs F, Sukharev SI, Suchyna TM (2015) Effects of Lys to Glu mutations in GsMTx4 on membrane binding, peptide orientation, and self-association propensity, as analyzed by molecular dynamics simulations. Biochim Biophys Acta 1848:2767-2778. CrossRef Medline

Nishizawa M, Nishizawa K (2007) Molecular dynamics simulations of a stretch-activated channel inhibitor GsMTx4 with lipid membranes: two binding modes and effects of lipid structure. Biophys J 92:4233-4243. CrossRef Medline

Onishi S, Ito T (1974) Calcium-induced phase separations in phosphatidylserine-phosphatidylcholine membranes. Biochemistry 13:881887. CrossRef Medline

Ostrow KL, Mammoser A, Suchyna T, Sachs F, Oswald R, Kubo S, Chino N, Gottlieb PA (2003) cDNA sequence and in vitro folding of GsMTx4, a specific peptide inhibitor of mechanosensitive channels. Toxicon 42:263274. CrossRef Medline

Oswald RE, Suchyna TM, McFeeters R, Gottlieb P, Sachs F (2002) Solution structure of peptide toxins that block mechanosensitive ion channels. J Biol Chem 277:34443-34450. CrossRef Medline

Palmer AR, Rosen S (2002) British society of audiology short papers meeting on experimental studies of hearing and deafness. Int J Audiol 41:231263. CrossRef

Pan B, Waguespack J, Schnee ME, LeBlanc C, Ricci AJ (2012) Permeation properties of the hair cell mechanotransducer channel provide insight into its molecular structure. J Neurophysiol 107:2408-2420. CrossRef Medline

Peng AW, Effertz T, Ricci AJ (2013) Adaptation of mammalian auditory hair cell mechanotransduction is independent of calcium entry. Neuron 80:960-972. CrossRef Medline

Perozo E, Kloda A, Cortes DM, Martinac B (2002) Physical principles underlying the transduction of bilayer deformation forces during mechanosensitive channel gating. Nat Struct Biol 9:696-703. CrossRef Medline

Persson I (2010) Hydrated metal ions in aqueous solution: How regular are their structures? Pure Appl Chem 82:1901-1917.

Petrov AG, Sachs F (2002) Flexoelectricity and elasticity of asymmetric biomembranes. Phys Rev E Stat Nonlin Soft Matter Phys 65:021905. CrossRef Medline

Pickles JO, Comis SD, Osborne MP (1984) Cross-links between stereocilia in the guinea pig organ of Corti, and their possible relation to sensory transduction. Hear Res 15:103-112. CrossRef Medline

Posokhov YO, Gottlieb PA, Ladokhin AS (2007a) Quenching-enhanced fluorescence titration protocol for accurate determination of free energy of membrane binding. Anal Biochem 362:290-292. CrossRef Medline

Posokhov YO, Gottlieb PA, Morales MJ, Sachs F, Ladokhin AS (2007b) Is lipid bilayer binding a common property of inhibitor cysteine knot ionchannel blockers? Biophys J 93:L20-L22. CrossRef Medline

Ricci AJ, Fettiplace R (1997) The effects of calcium buffering and cyclic AMP on mechano-electrical transduction in turtle auditory hair cells. J Physiol 501:111-124. CrossRef Medline

Ricci AJ, Fettiplace R (1998) Calcium permeation of the turtle hair cell mechanotransducer channel and its relation to the composition of endolymph. J Physiol 506:159-173. CrossRef Medline

Ricci AJ, Wu YC, Fettiplace R (1998) The endogenous calcium buffer and the time course of transducer adaptation in auditory hair cells. J Neurosci 18:8261-8277. Medline

Ricci AJ, Crawford AC, Fettiplace R (2000) Active hair bundle motion linked to fast transducer adaptation in auditory hair cells. J Neurosci 20:7131-7142. Medline

Ricci AJ, Kennedy HJ, Crawford AC, Fettiplace R (2005) The transduction channel filter in auditory hair cells. J Neurosci 25:7831-7839. CrossRef Medline

Sachs F (2010) Stretch-activated ion channels: what are they? Physiology (Bethesda) 25:50-56. CrossRef

Sachs F, Brownell WE, Petrov AG (2009) Membrane electromechanics in biology, with a focus on hearing. MRS Bull 34:665. CrossRef Medline

Stauffer EA, Holt JR (2007) Sensory transduction and adaptation in inner and outer hair cells of the mouse auditory system. J Neurophysiol 98: 3360-3369. CrossRef Medline

Stauffer EA, Scarborough JD, Hirono M, Miller ED, Shah K, Mercer JA, Holt JR, Gillespie PG (2005) Fast adaptation in vestibular hair cells requires Myosin-1c activity. Neuron 47:541-553. CrossRef Medline

Suchyna TM, Johnson JH, Hamer K, Leykam JF, Gage DA, Clemo HF, Baumgarten CM, Sachs F (2000) Identification of a peptide toxin from Grammostola spatulata spider venom that blocks cation-selective stretch-activated channels. J Gen Physiol 115:583-598. CrossRef Medline

Suchyna TM, Tape SE, Koeppe RE 2nd, Andersen OS, Sachs F, Gottlieb PA (2004) Bilayer-dependent inhibition of mechanosensitive channels 
by neuroactive peptide enantiomers. Nature 430:235-240. CrossRef Medline

Sukharev S, Sachs F (2012) Molecular force transduction by ion channels: diversity and unifying principles. J Cell Sci 125:3075-3083. CrossRef Medline

Thomas RC (2009) The plasma membrane calcium ATPase (PMCA) of neurones is electroneutral and exchanges $2 \mathrm{H}+$ for each $\mathrm{Ca} 2+$ or $\mathrm{Ba} 2+$ ion extruded. J Physiol 587:315-327. CrossRef Medline

Todorov AT, Petrov AG, Fendler JH (1994) First observation of the converse flexoelectric effect in bilayer lipid membranes. J Phys Chem 98: 3076-3079. CrossRef

Träuble H, Eibl H (1974) Electrostatic effects on lipid phase transitions: membrane structure and ionic environment. Proc Natl Acad Sci U S A 71:214-219. CrossRef Medline

Vyas MN, Jacobson BL, Quiocho FA (1989) The calcium-binding site in the galactose chemoreceptor protein. Crystallographic and metal-binding studies. J Biol Chem 264:20817-20821. Medline

Waguespack J, Salles FT, Kachar B, Ricci AJ (2007) Stepwise morphological and functional maturation of mechanotransduction in rat outer hair cells. J Neurosci 27:13890-13902. CrossRef Medline

Walker RG, Hudspeth AJ (1996) Calmodulin controls adaptation of mecha- noelectrical transduction by hair cells of the bullfrog's sacculus. Proc Natl Acad Sci U S A 93:2203-2207. CrossRef Medline

Wiggins P, Phillips R (2005) Membrane-protein interactions in mechanosensitive channels. Biophys J 88:880-902. CrossRef Medline

Wu YC, Ricci AJ, Fettiplace R (1999) Two components of transducer adaptation in auditory hair cells. J Neurophysiol 82:2171-2181. Medline

Xiong W, Grillet N, Elledge HM, Wagner TF, Zhao B, Johnson KR, Kazmierczak P, Müller U (2012) TMHS is an integral component of the mechanotransduction machinery of cochlear hair cells. Cell 151:1283-1295. CrossRef Medline

Zampini V, Rüttiger L, Johnson SL, Franz C, Furness DN, Waldhaus J, Xiong H, Hackney CM, Holley MC, Offenhauser N, Di Fiore PP, Knipper M, Masetto S, Marcotti W (2011) Eps8 regulates hair bundle length and functional maturation of mammalian auditory hair cells. PLoS Biol 9:e1001048. CrossRef Medline

Zhang PC, Keleshian AM, Sachs F (2001) Voltage-induced membrane movement. Nature 413:428-432. CrossRef Medline

Zhao B, Wu Z, Grillet N, Yan L, Xiong W, Harkins-Perry S, Müller U (2014) TMIE is an essential component of the mechanotransduction machinery of cochlear hair cells. Neuron 84:954-967. CrossRef Medline 